Historic, archived document

Do not assume content reflects current scientific knowledge, policies, or practices. 



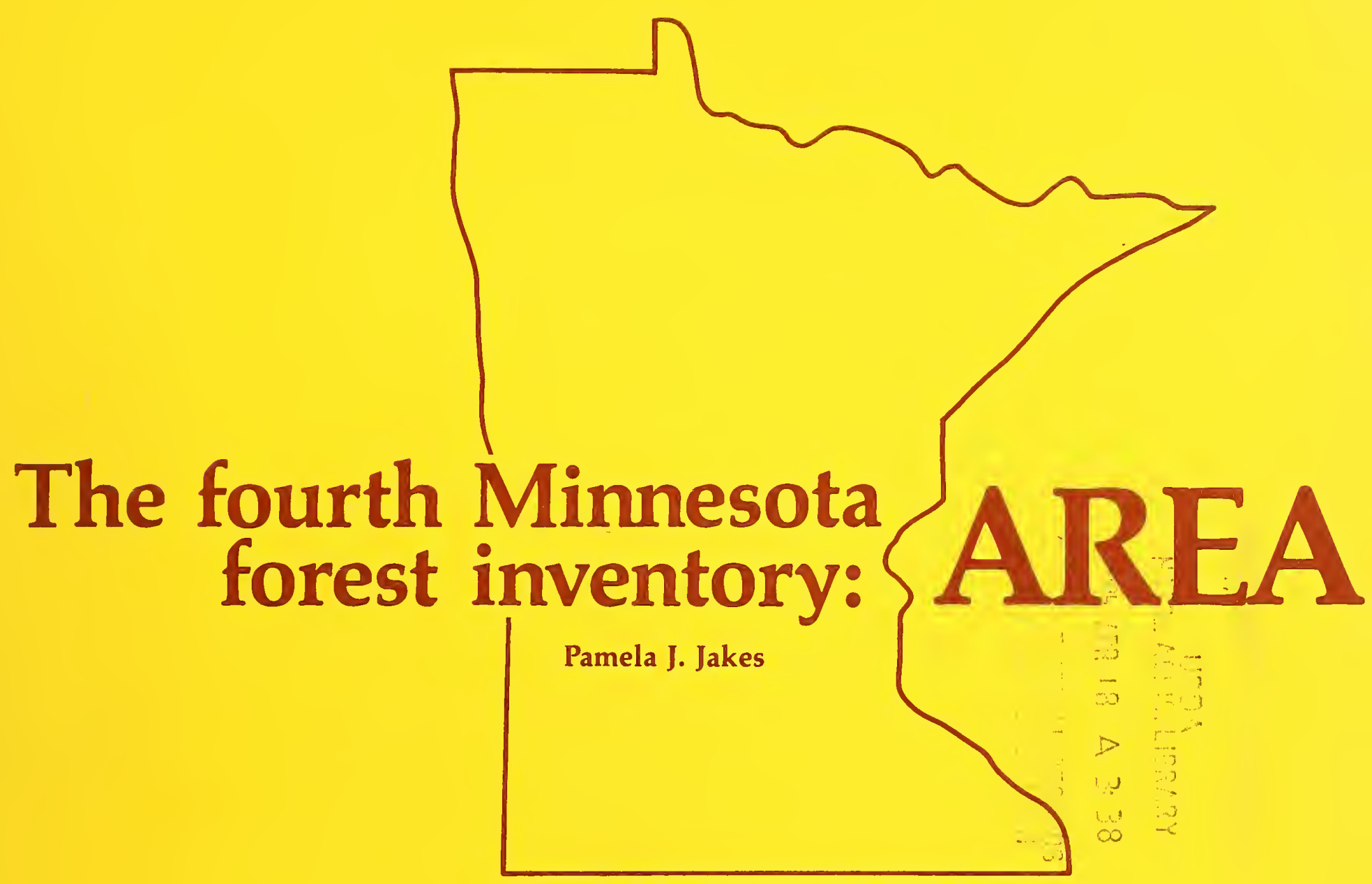

North Central Forest Experiment Station

Forest Service, U.S. Department of Agriculture

\section{LIBRARY}

FORESTRY SCIENCES LABORATORL

P. O. BOX 909

JUNEAU, ALASKA 99801 


\section{CONTENTS}

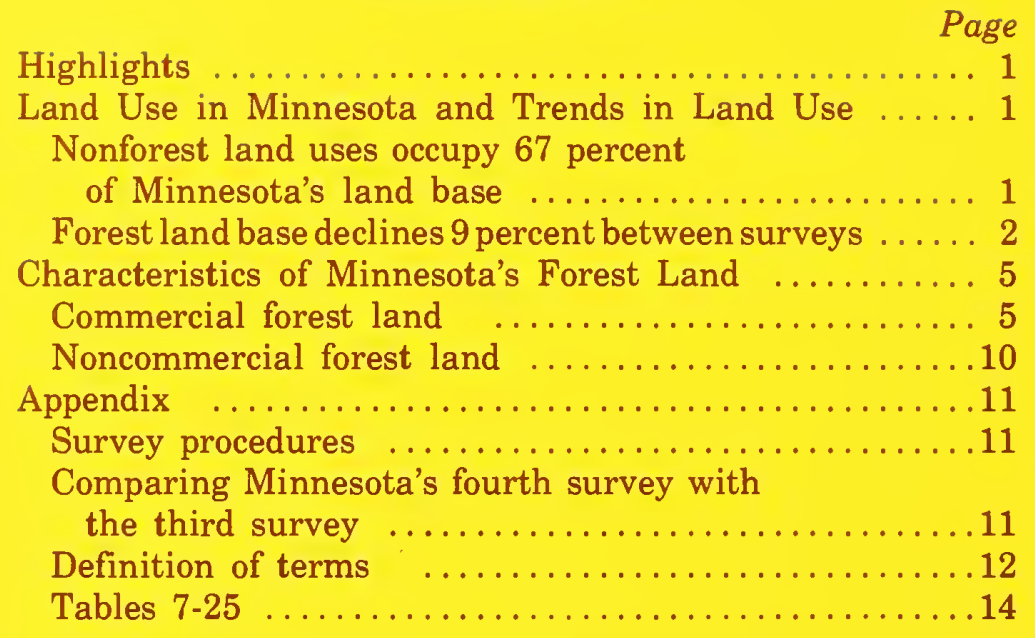

North Central Forest Experiment Station Forest Service-U.S. Department of Agriculture 1992 Folwell Avenue

St. Paul, Minnesota 55108

Manuscript approved for publication May 20, 1980 1980 


\section{FOREWORD}

Resources Evaluation (formerly called Forest Survey) is a continuing endeavor as mandated by the Forest and Rangeland Renewable Resources Planning Act of 1974, which was preceeded by the McSweeney-McNary Forest Research Act of 1928 . Its objective is to inventory periodically the Nation's forest lands to determine their extent, condition, and volumes of timber, growth, and depletions. This kind of up-to-date information is essential to frame intelligent forest policies and programs. USDA Forest Service regional experiment stations are charged with the responsibility for conducting these inventories and publishing summary reports for individual States. The North Central Forest Experiment Station is responsible for Resources Evaluation work done in Michigan, Wisconsin, Minnesota, North Dakota, eastern South Dakota (east of 103rd meridian), Nebraska, Iowa, Illinois, Indiana, Missouri, and Kansas.

Fieldwork for the 1977 Minnesota Forest Survey was started in July 1974 and was completed in July 1978. Reports on the three previous surveys of Minnesota's timber resource are dated 1936, 1953, and 1962.

Resource Bulletins reporting statistical highlights and detailed tables on the timber resource of the State and the four Survey Units are available from the Station. In addition to this report on area, Resource Bulletins are planned discussing Minnesota's timber volume, treatment opportunities, operability and biomass.

A higher degree of accuracy of survey information was obtained during the 1977 survey than otherwise would have been feasible because of intensified field sampling made possible by extra funding and manpower provided the North Central Station by the State Legislature through the Minnesota Department of Natural Resources. The Department also assisted in a canvass of primary wood-using plants in the State, which was used to help in estimating the quantity of timber products harvested in Minnesota.

Aerial photos used in the Minnesota Forest Inventory were furnished by the Boise Cascade Corporation, Chippewa National Forest, Lake County Land Commissioner's Office, Minnesota Department of Natural Resources, Superior National Forest, USDA Agricultural Stabilization and Conservation Service, and USDI Bureau of Indian Affairs.

The following North Central Forest Experiment Station office personnel assisted in preparation of the State tables and manuscript:

Mark H. Hansen, Associate biometrician

Mary Jean Hanson, Secretary

Patrick Peine, Statistical assistant

Gerhard K. Raile, Associate mensurationist

Carol Weist, Computer programmer 



\title{
THE FOURTH MINNESOTA FOREST INVENTORY: AREA
}

\author{
Pamela J. Jakes \\ Associate Resource Analyst
}

\section{HIGHLIGHTS}

- Nonforest land uses account for 34.0 million acres of the 50.7 million acres of land in the State.

- Since the third Minnesota Forest Inventory in 1962, forest area has declined 9 percent-from 18.4 million acres to 16.7 million acres.

- Commercial forest land is the largest forest land class, accounting for 13.7 million acres, or 82 percent of the forest land area.

- The 13.7 million acres of commercial forest land reported in 1977 is 1.7 million acres less ( 11 percent) than that reported in 1962.

- The aspen type dominates the forest landscape in 1977 as it did in 1962 , with 39 percent of the commercial forest area in aspen.

- A conifereous understory is present on 40 percent of Minnesota's commercial forest area.

- Farmers own one-quarter of Minnesota's commercial forest land, the largest portion for any ownership class.

- Poletimber stands are found on 7.0 million acres of commercial forest land, the remaining acreage is evenly divided between sawtimber and seedling and sapling stands.

- Half of the commercial forest area is within 1 mile of water.

- Eighty-two percent of Minnesota's commercial forest land is within 1 mile of a maintained road.

- Seventy-four percent of Minnesota commercial forest land is owned by individuals who own at least 100 acres of commercial forest.

A diversity of land uses are observed across the State of Minnesota. Moving from the Iowa-South Dakota-Minnesota border in the southwest to the
Arrowhead Region in the northeast, one travels though cropland, metropolitan centers, recreational developments, and valuable mineral deposits, to forest wilderness and the Great Lakes. Analysis of data from the fourth Minnesota Forest Inventory gives an indication of current land uses in the State, with particular emphasis on past and present conditions of Minnesota's commercial forest land.

\section{LAND USE IN MINNESOTA AND TRENDS IN LAND USE}

\section{Nonforest Land Uses Occupy 67 Percent of Minnesota's Land Base}

Resource Evaluation recognizes two primary categories of land use-forest and nonforest. Nonforest land accounts for 34.0 million acres of the 50.7 million acres of land in the State. Three classes of nonforest land-cropland, marsh, and urban and other uses-account for more than 93 percent of the total nonforest land area:
Nonforest land use

Cropland

Marsh

Urban and other uses

Improved pasture

Other farm-farmstead, idle farm

Wooded strips, windbreaks, wooded pasture

Noncensus water

Total
Million acres

26.5

3.0

2.4

1.0

0.6

0.4

$\frac{0.1}{34.0}$
Minnesota's nonforest land is concentrated in the Prairie and Central Hardwood Forest Survey Units (fig. 1). Nonforest land uses that do not fit this generalization include marshland (49 percent in the Northern Pine Unit) and idle farmland (43 percent in the Northern Pine Unit, 31 percent in the AspenBirch Unit). 
NORTHERN

PINE

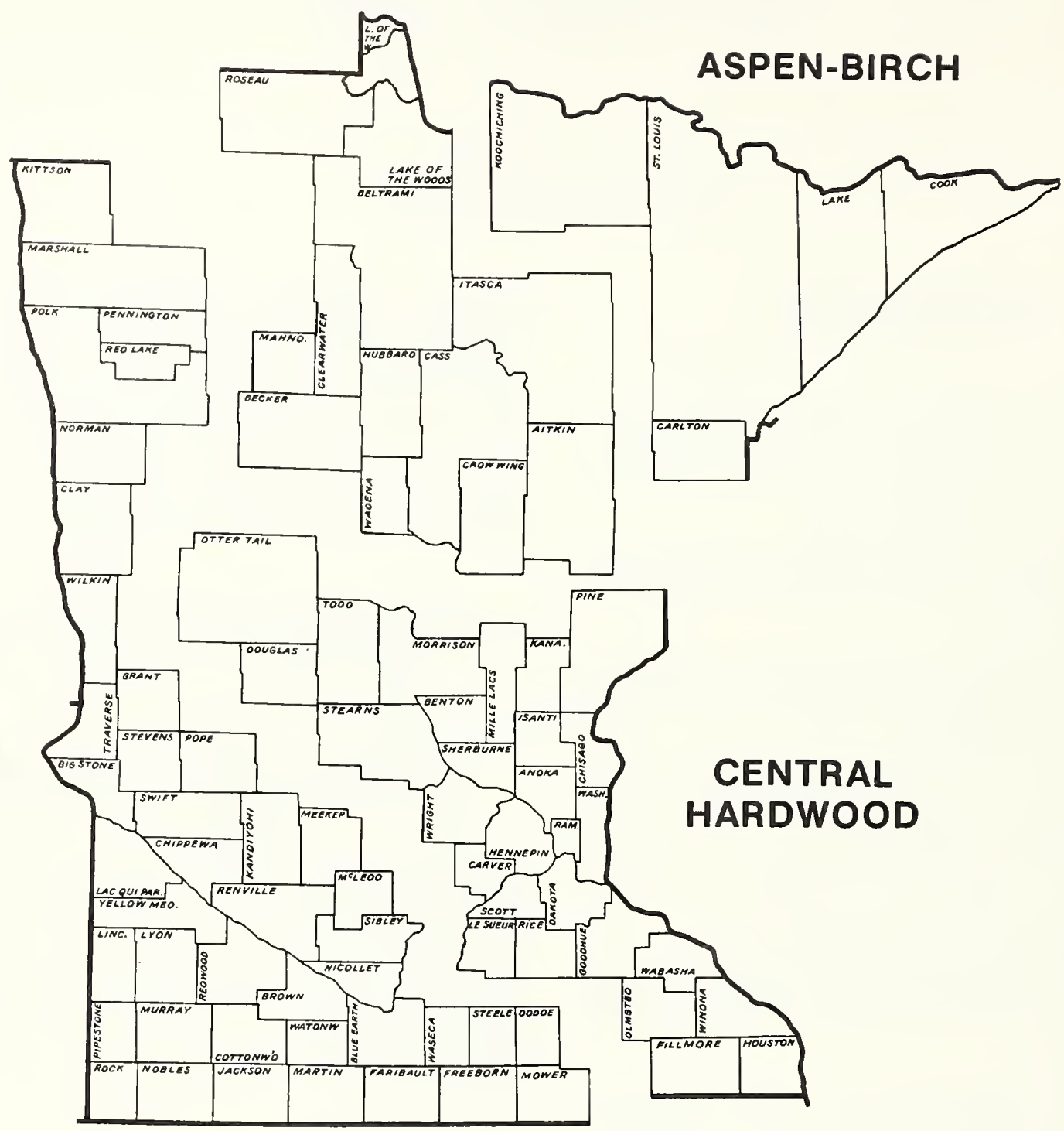

PRAIRIE

Figure 1.-Minnesota's four Forest Survey Units.

\section{Forest Land Base Declines 9 Percent Between Surveys}

The forest land base in Minnesota covers 16.7 million acres, 33 percent of the State's land area. Since the third Minnesota Inventory in 1962, forest area has declined 9 percent-from 18.4 million acres to 16.7 million acres (table 1). Forest land is subdivided into three land classes-commercial forest land, productive-reserved forest land, and unproductive forest land. Commercial forest land is the largest forest land class, accounting for 13.7 million acres, or 82 percent of the forest land area. 
Table 1.-Area of land by land class, Minnesota, $1962^{1}$ and 1977

(In thousand acres)

\begin{tabular}{lrr}
\hline Land class & \multicolumn{1}{c}{$196 \mathbf{2}^{1}$} & \multicolumn{1}{c}{1977} \\
\hline FOREST: & & \\
Commercial forest land: & & \\
Jack pine & 872.0 & 504.4 \\
Red pine & 280.6 & 246.9 \\
White pine & 132.0 & 65.6 \\
Balsam fir & 907.9 & 859.1 \\
White spruce & 57.3 & 79.2 \\
Black spruce & $1,152.3$ & $1,041.8$ \\
Northern white-cedar & 333.7 & 498.6 \\
Tamarack & 470.5 & 465.4 \\
Oak-hickory & $1,022.7$ & 893.9 \\
Elm-ash-cottonwood & $1,286.4$ & 738.1 \\
Maple-basswood & $1,004.3$ & $1,283.9$ \\
Aspen & $5,399.8$ & $5,302.3$ \\
Paper birch & 795.1 & 997.6 \\
Balsam poplar & 447.5 & 548.9 \\
Nonstocked & $1,249.7$ & 169.4 \\
$\quad$ Subtotal & $15,411.8$ & $13,695.1$ \\
Noncommercial forest land: & & \\
Unproductive & $2,563.1$ & $1,835.5$ \\
Productive-reserved & 470.1 & $1,178.6$ \\
$\quad$ Subtotal & $3,333.2$ & $3,014.1$ \\
Total & $18,445.0$ & $16,709.2$ \\
NONFOREST LAND: & $32,760.8$ & $34,035.6$ \\
$\quad$ Total & $51,205.8$ & $50,744.8$ \\
\hline IFigus & & \\
\hline
\end{tabular}

${ }^{1}$ Figures have been adjusted from those published after the 1962 survey to conform to 1977 areas because of changes in survey procedures and definitions.

\section{Commercial forest area}

Commercial forest area declines 11 percent between 1962 and 1977.- The 13.7 million acres of commercial forest land reported in 1977 is 1.7 million acres less than that reported in 1962. This decrease in area translates to an annual rate of change of $(-) 0.8$ percent. During the same time period, the rate of change in commercial forest area in the Lake States Region was (-)0.3 percent. In Minnesota, a large portion ( 0.7 million acres) of the area of commercial forest land lost between surveys remained classified as forest land, but was placed in productive-reserved status. This transfer to productive-reserved forest land occurred in the following forest types:
Forest type

Jack pine

Red pine

White pine

Balsam fir

White spruce

Black spruce

Northern white-cedar

Tamarack

Oak-hickory

Elm-ash-cottonwood

Maple-basswood

Aspen

Paper birch

Balsam poplar

Nonstocked

Total
Thousand acres

96.0

24.0

6.1

26.5

3.5

53.1

12.1

0.2

6.4

8.5

362.0

72.6

0.2

1.9

673.1
Creation of the Voyageurs National Park and expansion of the protected portions of the Boundary Waters Canoe Area accounted for more than 90 percent of the total transfer of commercial forest land to productive-reserved forest land. The other two Lake States have not experienced such a sharp increase in the area of productive-reserved forest land, which largely accounts for the difference in the annual rates of change in commercial forest area between Minnesota and the Lake States Region.

More than 1.0 million acres of commercial forest land was converted to nonforest land uses between 1962 and 1977. Urban and other uses, cropland, and improved pasture absorbed large amounts of commercial forest land (fig. 2).

Most of Minnesota's commercial forest land undisturbed between surveys.-When crews visit the field plots, they record any disturbance or vegetative change occurring in the recent past that has been instrumental in creating present stand conditions. Since Station crews only visit plots outside the National Forests (the National Forests supplied their own inventory data), stand history is only available for $\mathbf{1 2 . 0}$ million acres of non-National Forest commercial forest land.

Stand history information shows that most (86 percent) of the commercial forest land was undisturbed between surveys (table 2). The current conditions of these stands are the result of natural succession rather than a catastrophic natural disturbance or human interference. 
Figure 2-Conversion of commercial forest land

to other land uses between 1962 and

1977, Minnesota.

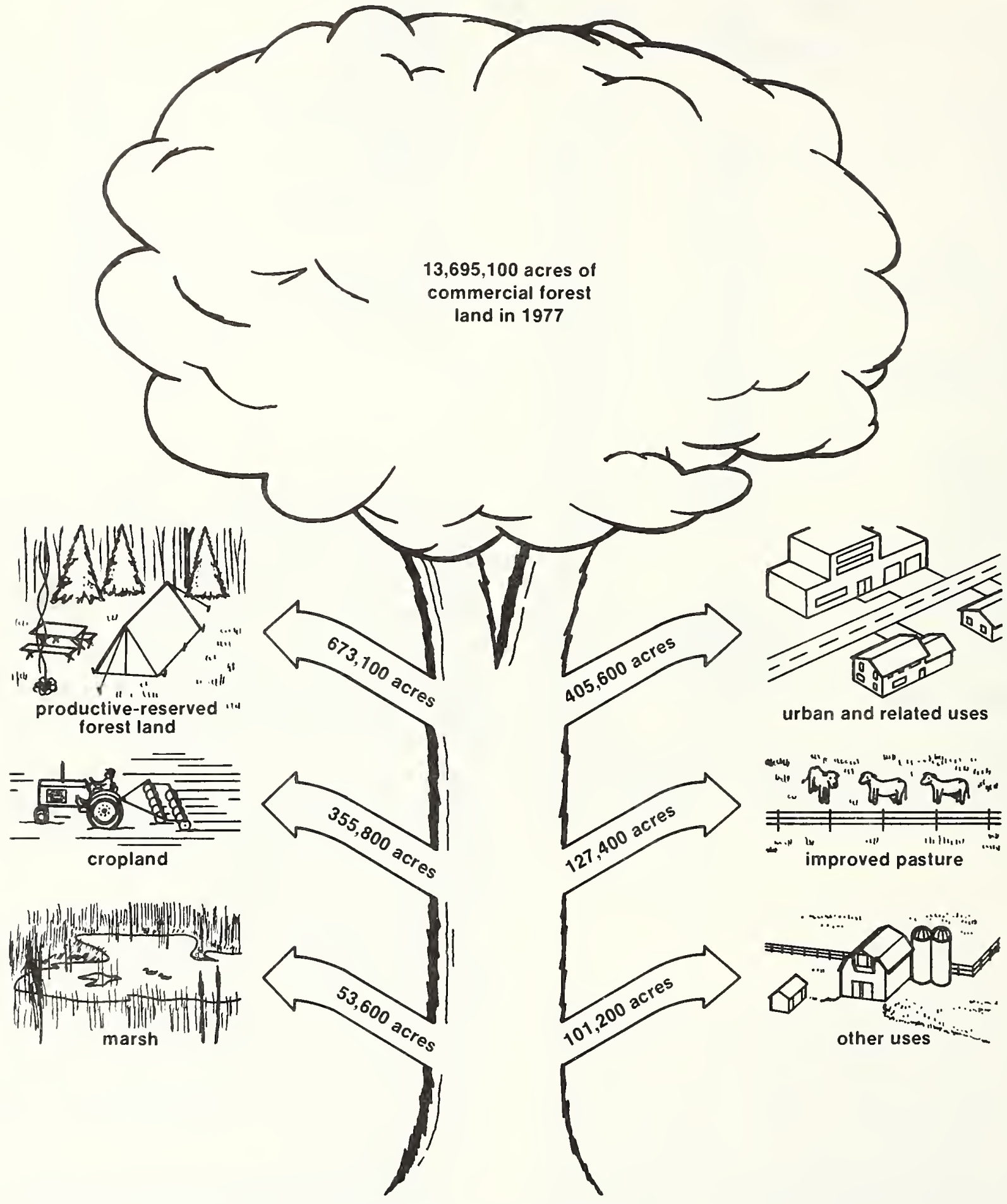

$15,411,800$ acres of commercial

forest land in 1962

Figure 2.-Conversion of commercial forest land to other land uses between 1962 and 1977, Minnesota. 
Table 2.-Area of commercial forest land (except National Forest) by treatment class and ownership class, Minnesota, 1962-1977

(In thousand acres)

\begin{tabular}{|c|c|c|c|c|c|}
\hline \multirow[b]{2}{*}{$\begin{array}{l}\text { Treatments } \\
\text { since } 1962\end{array}$} & \multirow[b]{2}{*}{ Total } & \multicolumn{4}{|c|}{ Ownership class } \\
\hline & & Public $^{1}$ & $\begin{array}{l}\text { Forest } \\
\text { industry }\end{array}$ & Farmer & $\begin{array}{r}\text { Miscellaneous } \\
\text { private }\end{array}$ \\
\hline No disturbance & $10,325.5$ & $4,924.9$ & 612.8 & $2,861.5$ & $1,927.3$ \\
\hline Timber stand improvement & 30.2 & 7.9 & 4.2 & 9.6 & 8.5 \\
\hline Harvest & $1,207.2$ & 515.8 & 118.5 & 407.9 & 165.0 \\
\hline Significant damage & 344.3 & 131.3 & 24.3 & 112.3 & 76.4 \\
\hline \multicolumn{6}{|l|}{ Artificial regeneration } \\
\hline Forest land & 53.2 & 28.0 & 13.2 & 3.1 & 8.9 \\
\hline Nonforest land & 6.4 & 1.2 & - & 3.3 & 1.9 \\
\hline \multicolumn{6}{|l|}{ Natural regeneration } \\
\hline Nonforest land & 13.2 & 4.2 & - & 6.0 & 3.0 \\
\hline Total & $11,980.0$ & $5,613.3$ & 772.0 & $3,403.7$ & $2,191.0$ \\
\hline
\end{tabular}

${ }^{1}$ Does not include National Forest land.

The most common treatment was harvest, occuring on 1.2 million acres. Harvest acreage was concentrated in public and farmer ownership classes, with 515,800 and 407,900 acres of harvest, respectively. Fifteen percent of forest industry commercial forest land was harvested over the 15-year period, as was 12 percent of farmer, 9 percent of public, and 7 percent of miscellaneous private commercial forest land. Commercial forest land in the aspen forest type accounted for the largest portion of the harvest area, 45 percent. Fifteen percent of the red pine type acreage was harvested since the last survey.

Significant damage was observed on 344,300 acres of commercial forest land. Most of the damage ( 84 percent) was due to natural causes, such as fire, insects, disease, and wind. However, human interference (such as draining and flooding) resulted in significant damage on 56,700 acres.

Stand history records indicate that artificial regeneration occurred on 53,200 acres of commercial forest land and timber stand improvement projects on 30,200 acres. Nonforest land was converted to commercial forest land through natural $(13,200$ acres) and artificial (6,400 acres) regeneration.

\section{Noncommercial forest area declines}

The area of noncommercial forest land remained relatively constant during the 15 years between forest inventories. The 3.0 million acres of noncommercial forest land in 1977 is only 19,100 acres less than that reported in 1962.
Within the noncommercial forest land class, the area of productive-reserved forest land has more than doubled, from 0.5 million acres in 1962 to 1.2 million acres in 1977. This increase is the result of commercial forest and unproductive land being transfered to parks, wilderness areas, and Christmas tree plantations. The area of unproductive forest land declined 28 percent between 1962 and 1977, from 2.6 million acres to 1.8 million acres. Although data on changes in land-use on unproductive forest land were not gathered during the fourth Minnesota Forest Inventory, it has been generally observed that in the northern portions of the State, unproductive forest land has been transfered to productive-reserved status or reclassified as water or marsh; while in the southern portions of the State, unproductive forest land has been converted to pasture and urban and related land uses.

\section{CHARACTERISTICS OF MINNESOTA'S FOREST LAND}

\section{Commercial Forest Land}

- Aspen is Minnesota's most common forest type

The aspen forest dominates the Minnesota forest landscape in 1977 as it did in 1962 . The area of aspen declined slightly from 5.4 million acres in 1962 and 5.3 million acres in 1977; however, the percentage of land covered by aspen increased from 35 percent to 39 percent. Commercial forest area declined in most 
forest types between surveys, except for white spruce, northern white-cedar, maple-basswood, paper birch, and balsam poplar. The elm-ash-cottonwood type lost the most acreage between surveys $(548,300)$, while the white pine type lost the largest percentage of its 1962 area (50 percent).

Survey data cannot explain totally the change in commercial forest area by forest type. As shown earlier, the acreage transfered to productive-reserved forest land is known by forest type, but comparing these acreages to the total change between surveys in each type indicates that this is only part of the story. Each type lost land to nonforest uses, but nonforest land has also reverted to commercial forest land and there have been shifts in forest types within the commercial forest land base.

Coniferous understory present on 40 percent of Minnesota's commercial forest land

Forest types classify commercial forest land on the basis of the tree species forming a plurality of the stocking. It is often useful to know the understory of a stand in order to identify what species may occupy a site if the overstory is harvested, and to help determine wildlife habitat diversity. Inventory data were collected indicating whether coniferous understory was present, whether the understory was planted or natural, and whether the understory would prosper if the present stand was harvested. A coniferous understory is present on 40 percent of Minnesota's commercial forest land (table 3 ). Of the 5.5 million acres of commercial forest land with coniferous understory, 97 percent occurs naturally, 3 percent is planted.

Coniferous understory is found in all forest types. Planting of a coniferous understory is most common in aspen and jack pine types, while coniferous understory naturally occurs most often in aspen, black spruce, and balsam fir forest types. More than 96 percent of the understory acreage would survive if the current stand was removed, the remaining commercial forest area would require additional treatments for the understory to survive.

Farmers own one-quarter of Minnesota's commercial forest land

Farmers own more commercial forest land than any other group (fig. 3). The 3.4 million acres of

Table 3.-Area of commercial forest land by forest type and presence and condition of coniferous understory, Minnesota, 1977

(In thousand acres)

\begin{tabular}{|c|c|c|c|c|c|c|}
\hline \multirow[b]{3}{*}{ Forest type } & \multirow[b]{3}{*}{ Total } & \multirow[b]{3}{*}{$\begin{array}{c}\text { No coniferous } \\
\text { understory }\end{array}$} & \multicolumn{4}{|c|}{ Conifer understory } \\
\hline & & & \multicolumn{2}{|c|}{ Planted } & \multicolumn{2}{|c|}{ Natural } \\
\hline & & & Good $^{1}$ & Poor ${ }^{2}$ & Good $^{1}$ & Poor $^{2}$ \\
\hline Jack pine & 504.4 & 201.9 & 39.4 & 8.2 & 244.6 & 10.3 \\
\hline Redpine & 246.9 & 49.3 & 20.8 & 3.4 & 173.0 & 0.4 \\
\hline Whitepine & 65.6 & 16.1 & 1.1 & - & 48.4 & - \\
\hline Balsam fir & 859.1 & 84.1 & 2.3 & 6.0 & 750.0 & 16.7 \\
\hline White spruce & 79.2 & 10.9 & 13.9 & 5.1 & 42.4 & 6.9 \\
\hline Black spruce & $1,041.8$ & 128.4 & 2.5 & 10.0 & 896.4 & 4.5 \\
\hline \multicolumn{7}{|l|}{ Northern } \\
\hline white-cedar & 498.6 & 65.1 & 1.4 & - & 421.9 & 10.2 \\
\hline Tamarack & 465.4 & 134.8 & 1.7 & 4.0 & 323.7 & 1.2 \\
\hline Oak & 893.9 & 854.4 & 6.5 & 3.1 & 24.6 & 5.3 \\
\hline Elm-ash-cottonwood & 738.1 & 518.4 & 1.1 & 2.8 & 204.3 & 11.5 \\
\hline Maple-basswood & $1,283.9$ & $1,095.6$ & 5.3 & 1.5 & 171.2 & 10.3 \\
\hline Aspen & $5,302.3$ & $3,877.6$ & 32.7 & 32.8 & $1,302.2$ & 57.0 \\
\hline Paper birch & 997.6 & 555.2 & 1.4 & 7.0 & 411.8 & 222.2 \\
\hline Balsam poplar & 548.9 & 417.8 & - & 1.6 & 120.0 & 9.5 \\
\hline Nonstocked & 169.4 & 126.7 & - & - & 36.9 & 5.8 \\
\hline Total & $13,695.1$ & $8,163.3$ & 130.1 & 85.5 & $5,171.4$ & 171.8 \\
\hline
\end{tabular}

${ }^{1}$ Should prosper when present stand is removed.

${ }^{2}$ In order to prosper, stand would require treatment other than a regeneration cut. 


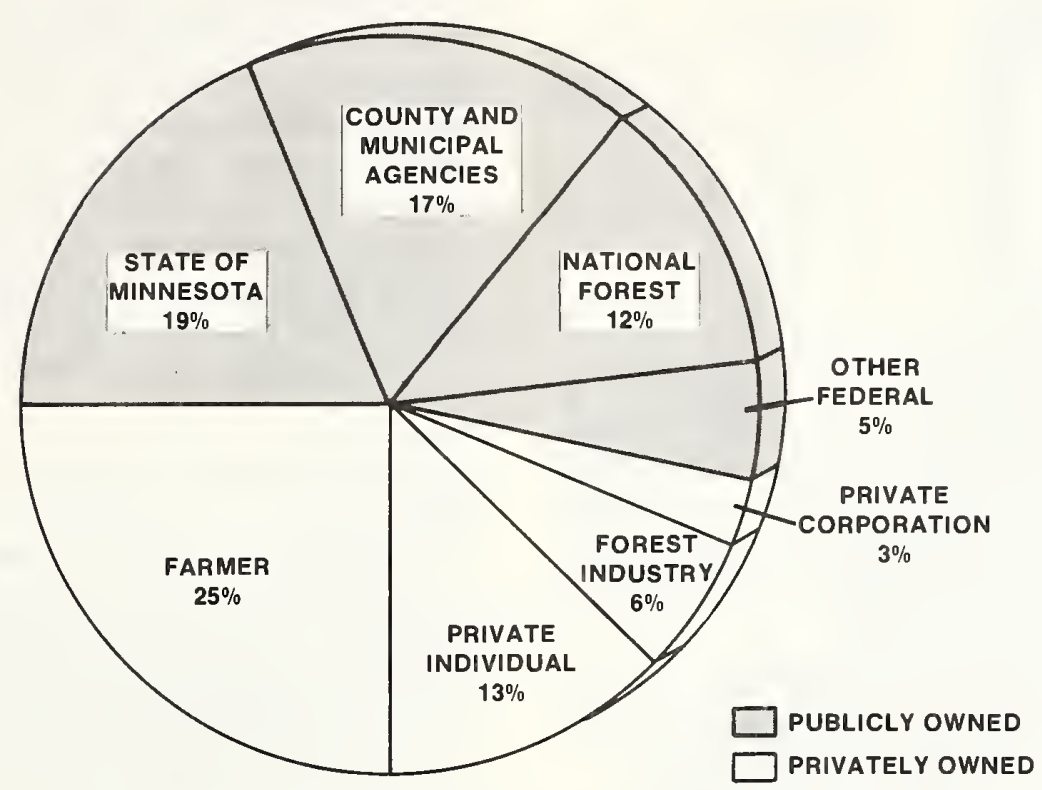

Figure 3.-Distribution of commercial forest land by ownership class, Minnesota, 1977.

mer owned commercial forest land is concentrated in the Northern Pine and Central Hardwood Forest Survey Units (1.3 million acres and 1.1 million acres respectively). More than one-third of the commercial forest land owned by farmers is owned by individuals having at least 100 acres of commercial forest land. An additional 55 percent of the farmer-owned commercial forest land is owned by individuals having between 20 and 100 acres.

The State of Minnesota owns 2.7 million acres of commercial forest land, 89 percent of which occurs in the Aspen-Birch and Northern Pine Forest Survey Units. An additional 2.3 million acres of commercial forest land is owned by county and municipal agencies. Minnesota commercial forest land in county and municipal ownership accounts for 34 percent of all the county and municipal commercial forest land in the United States. Except for the State of Wisconsin, no other State has more than 400,000 acres of commercial forest land in the county and municipal ownership class.

National Forest and miscellaneous private individual owners each hold 1.7 million acres of commercial forest land. The remaining 1.9 million acres of commercial forest land is owned by forest industry, private corporations, and other federal agencies.
Majority of commercial forest area in stands less than 51 years old

Forest stands over 50 years of age occupy 43 percent of Minnesota's commercial forest land (fig. 4). The distribution of commercial forest land by age class is fairly consistent across ownership classes; however, the distribution varies by forest type.

Distribution of type acreage by age class reflects stand history and the silvics of the species common to the type. In the aspen type, 90 percent of the acreage is in stands less than 61 years old. The occurrence of aspen in Minnesota is strongly tied to the fire history of the State. Large areas of northern Minnesota burned in the early part of this century, causing the destruction of existing stands and regeneration of aspen that has resulted in the current 60- to 70-yearold stands. Few aspen stands reach over 70 years of age-either the stands are harvested on relatively short rotations or they decline from attacks by insects or disease. By comparison, only 51 percent of the red pine type acreage is in stands less than 61 years old. Red pine is a relatively fire tolerant species. It is managed for sawtimber so therefore is harvested on much longer rotations than aspen. 


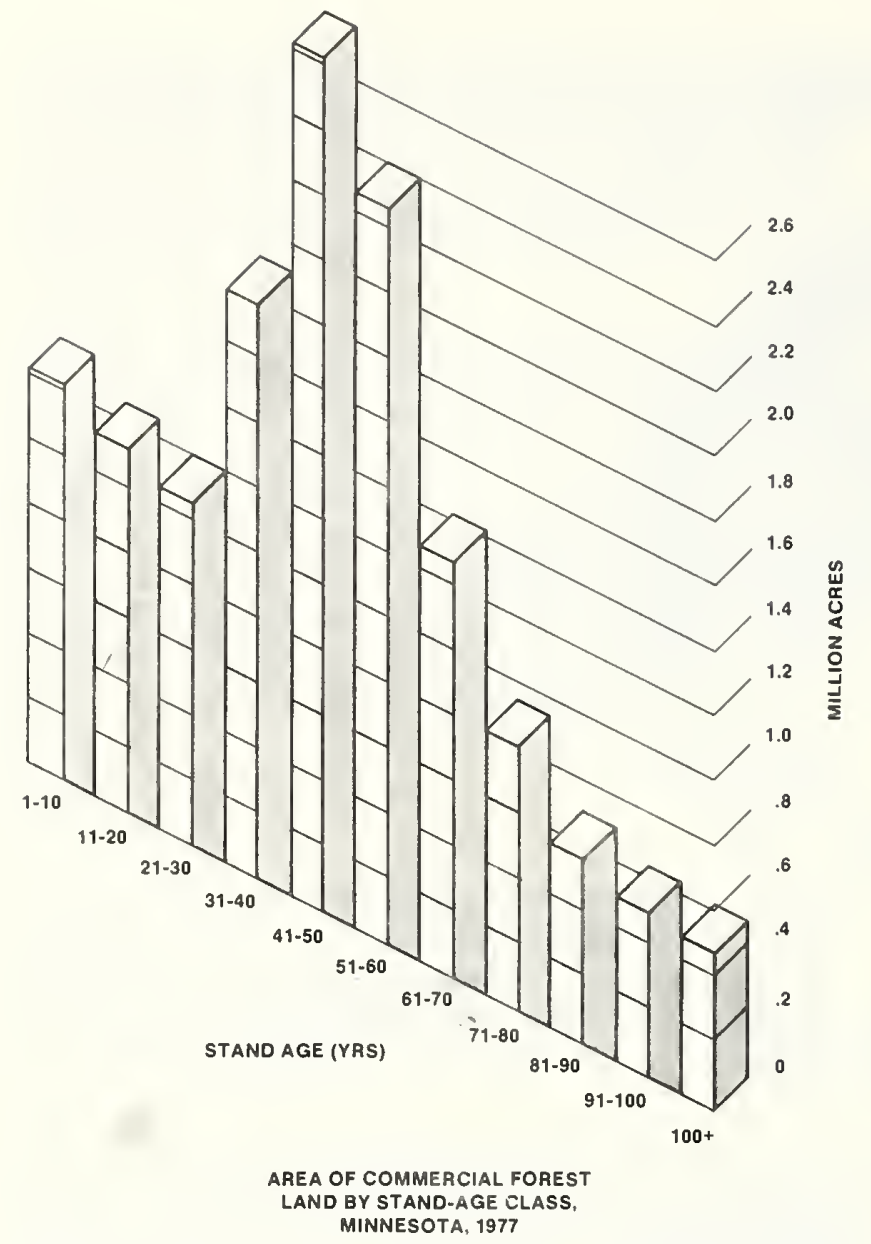

Figure 4.-Area of commercial forest land by standage class, Minnesota, 1977.
Poletimber stands occupy majority of commercial forest land

Poletimber stands are found on 7.0 million acres of commercial forest land in Minnesota, the remaining acreage is evenly divided between sawtimber and seedling and sapling stands. Although most forest types have the largest portion of their commercial forest area in poletimber stands, there are some exceptions. Red pine, oak-hickory, and maple-basswood forest types have a majority of their acreage in sawtimber stands, while white spruce and tamarack have a majority in seedling and sapling stands.

Three ratings of forest site quality collected in Minnesota

Physiographic classes.-Physiographic classes describe soil and water conditions that affect forest type and site quality. Five physiographic classes were recorded in Minnesota, ranging from xeric sites, where excessive drainage limits growth and species occurrence, to hydric sites, where excess water is the limiting factor (table 4). Two-thirds of Minnesota's commercial forest land occurs on mesic sites. Soil and water characteristics on mesic sites are favorable to tree growth-growth and species occurrence are limited only by climate. In a State so well known for its lakes and streams, it is not surprising that it is much more common for growth and species occurrence to be

Table 4.- Area of commercial forest land by forest type and physiographic class, Minnesota 1977

(In thousand acres)

\begin{tabular}{|c|c|c|c|c|c|c|}
\hline \multirow[b]{2}{*}{ Forest type } & \multirow[b]{2}{*}{ Total } & \multicolumn{5}{|c|}{ Physiographic class } \\
\hline & & Xeric & Xeromesic & Mesic & Hydromesic & Hydric \\
\hline Jack pine & 504.4 & 7.7 & 204.1 & 275.6 & 15.4 & 1.6 \\
\hline Red pine & 246.9 & - & 73.4 & 167.6 & 5.9 & - \\
\hline White pine & 65.6 & - & 19.3 & 44.6 & 1.7 & - \\
\hline Balsam fir & 859.1 & - & 17.4 & 528.3 & 260.1 & 53.3 \\
\hline White spruce & 79.2 & - & 1.7 & 56.9 & 18.6 & 2.0 \\
\hline Black spruce & $1,041.8$ & - & 4.0 & 65.9 & 588.4 & 383.5 \\
\hline \multicolumn{7}{|l|}{ Northern } \\
\hline white-cedar & 498.6 & - & - & 43.9 & 323.4 & 131.3 \\
\hline Tamarack & 465.4 & - & - & 7.3 & 327.3 & 130.8 \\
\hline Oak-hickory & 893.9 & 1.5 & 41.8 & 839.0 & 11.6 & - \\
\hline Elm-ash-cottonwood & 738.1 & - & - & 212.5 & 488.0 & 37.6 \\
\hline Maple-basswood & $1,283.9$ & - & 6.6 & $1,042.1$ & 228.7 & 6.5 \\
\hline Aspen & $5,302.3$ & 12.0 & 84.5 & $4,596.5$ & 584.3 & 25.0 \\
\hline Paper birch & 997.6 & - & 22.5 & 873.7 & 93.1 & 8.3 \\
\hline Balsam poplar & 548.9 & 1.4 & 4.0 & 344.4 & 190.6 & 8.5 \\
\hline Nonstocked & 169.4 & - & 6.1 & 34.2 & 84.1 & 45.0 \\
\hline Total & $13,695.1$ & 22.6 & 485.4 & $9,132.5$ & $3,221.2$ & 833.4 \\
\hline
\end{tabular}


limited by excess water than by droughty conditions. Hydric or hydromesic sites are found on 4.1 million acres of commercial forest land as compared to 0.5 million acres on xeric or xeromesic sites.

In most forest types, the majority of the commercial forest land is on mesic sites. Forest types more common on wetter sites include black spruce, northern white-cedar, tamarack, and elm-ash-cottonwood. Only four forest types are found on the very dry xeric sites-jack pine, oak-hickory, aspen, and balsam poplar.

Site index classes.-Physiographic classes give an indication of forest site quality based on soil and water conditions. A second expression of site quality, site index, classifies sites in terms of the height of a free-growing dominant or codominant tree of a representative species of the forest type at age 50 . There is a relation between physiographic class and site index, as illustrated in the tabulation below:

$\begin{array}{cc}\text { Physiographic class } & \text { for all forest types } \\ \text { Xeric } & 56 \\ \text { Xeromesic } & 57 \\ \text { Mesic } & 61 \\ \text { Hydromesic } & 48 \\ \text { Hydric } & 33\end{array}$

From this data it appears that in Minnesota, excessive water has a greater impact on tree height growth than a lack of water.

Site index values vary widely by forest type. A site index value that is excellent for one type may be only average for a second type. For example, in the aspen type, the average site index is 66 . Ten percent of the aspen acreage has a site index value of at least 81 . The best white spruce sites in Minnesota fall in the 61-70 site index class, the same class that contains the average aspen site index. Therefore, in Minnesota, commercial forest land in the 61-70 site index class would be called excellent if it were supporting white spruce, but only average if supporting aspen.

Site classes.-Yet a third descriptor of site quality is site class. Site classes are expressed in cubic feet of growth per acre per year, and classify a site in terms of its inherent capacity to grow crops of wood based on culmination of mean annual increment for fullystocked natural stands.
In Minnesota, 6 site classes were recognized:

$\begin{array}{cc}\text { Site class } & \begin{array}{c}\text { Cubic foot } \\ \text { growth/acre/year }\end{array} \\ \text { I } & 225+ \\ \text { II } & 165-224 \\ \text { III } & 120-164 \\ \text { IV } & 85-119 \\ \text { V } & 50-84 \\ \text { VI } & 20-49\end{array}$

The average site class rating in Minnesota is 58 (site class V), which is average for the three Lake States (55, site class V). This means that on the average, a fully-stocked natural stand will produce 58 cubic feet/acre/year at culmination of mean annual increment in Minnesota.

New survey data provides more detailed picture of Minnesota's commercial forest land

Data on distance to water, distance to a road, stand area, and size of owner are several pieces of information collected for the first time in Minnesota during the fourth Forest Inventory. Analysts at the North Central Station hope to eventually develop this data to provide an assessment of the operability of Minnesota's commercial forest land and nontimber forest resources.

For example, accessibility and economies of scale are two important variables affecting a decision to harvest or manage a timber stand. Distance to road gives an indication of the accessibility of a stand, while stand area estimates the extent of a specific forest type, stand-size class, and density, and thereby the area suitable for a given treatment. Prime recreation sites are often occupied by mature stands of timber, and are close to a lake or stream, with easy access. Information on stand area, distance to water, and distance to road can be analyzed to assess an area's recreational potential.

Distance to water.-Forty-five percent of Minnesota's commercial forest land is within 1 mile of water. A comparison of the average distance to water for different forest types produces some surprising relations. For example, the average distance to water for the tamarack forest type is 3.8 miles, the average distance for all forest types is 2.3 miles. Distance to water is measured on a straight line to the nearest lake at least 5 acres in size or the nearest stream at least 1 chain wide. So while tamarack is often found on sites with poor drainage or even standing water 
(98 percent of the type's commercial forest acreage is on hydromesic or hydric sites), the distance to open water is often over 3 miles.

Distance to road.-Eighty-two percent of Minnesota's commercial forest land is within 1 mile of a maintained road (a road that is graded at least once a year). Of the area more than 20 miles from a road, over three-quarters is in public ownership. Forty percent of the commercial forest area more than 20 miles from a road is black spruce or tamarack forest type. These areas are most likely bogs and marshes.

Stand area.- Stand area is a measure of the homogeneity of Minnesota's commercial forest land. Stand area measures the extent of a given type-size-density class. For example, in the $640+$ stand-area class, there are 19,100 acres in the jack pine forest type. This means that there are no more than 30 parcels of jack pine at least 640 acres in size and of the same stand-size and density. Most (65 percent) of Minnesota's commercial forest land is in homogeneous typesize-density blocks of less than 20 acres.

Size of owner.-This data indicates the amount of commercial forest acreage owned by one individual or agency. Since one entity can own several tracts of timber, size of owner shows the total commercial forest acreage owned by the individual or agency. Seventy-four percent of Minnesota's commercial forest land is owned by individuals or agencies who own at least 100 acres of commercial forest.

This statistic is colored by the fact that all public owners hold at least 5,000 acres. Looking at just private owners, 99 percent of Minnesota's forest industries, 42 percent of miscellaneous private owners, and 33 percent of farmers own at least 100 acres of commercial forest land.

\section{Noncommercial Forest Land}

Forest inventory data collected on noncommercial forest land was primarily limited to acreage by ownership class and forest type (tables 5 and 6 ).

\section{Unproductive forest land}

The State's 1.8 million acres of unproductive forest land is 11 percent of the total forest area. Unproductive land is concentrated in State, county, and municipal ownership, with 1.3 million acres. Over 19 percent of the forest land in this ownership class is unproductive, as compared to 14 percent for federal owners other than National Forest, and less than 6 percent for all other ownership classes.

The black spruce forest type occurs on 56 percent of the State's unproductive forest land. There is nearly as much black spruce in the unproductive forest land class as there is in the commercial forest land class-1,032,400 acres and 1,041,800 acres, respectively.

\section{Productive-reserved forest land}

Productive-reserved forest land totals 1.2 million acres. Public ownership classes hold 99 percent of the total as parks and wilderness areas account for all but a small portion of the productive-reserved area. The 11,600 acres of productive-reserved land in miscellaneous private ownership are primarily Christmas tree plantations. More than half of the productive-reserved area is in the aspen forest type, with jack pine and spruce-fir types contributing additional large acreage.

Table 5.-Area of forest land by ownership class and land class, Minnesota, 1977

(In thousand acres)

\begin{tabular}{|c|c|c|c|c|}
\hline \multirow[b]{2}{*}{ Ownership class } & \multirow[b]{2}{*}{$\begin{array}{l}\text { Total } \\
\text { forest }\end{array}$} & \multirow[b]{2}{*}{ Commercial } & \multicolumn{2}{|c|}{ Noncommercial } \\
\hline & & & Unproductive & $\begin{array}{l}\text { Productive- } \\
\text { reserved }\end{array}$ \\
\hline National Forest & $2,599.4$ & $1,715.1$ & 125.6 & 758.7 \\
\hline Other federal & 875.0 & 621.2 & 127.1 & 126.7 \\
\hline State, county, and municipal & $6,552.4$ & $4,992.1$ & $1,278.7$ & 281.6 \\
\hline Forest industry & 807.2 & 772.0 & 35.2 & - \\
\hline Farmer & $3,614.8$ & $3,403.7$ & 211.1 & 一 \\
\hline \multicolumn{5}{|l|}{ Miscellaneous } \\
\hline private & $2,260.4$ & $2,191.0$ & 57.8 & 11.6 \\
\hline Total & $16,709.2$ & $13,695.1$ & $1,835.5$ & $1,178.6$ \\
\hline
\end{tabular}


Table 6.-Area of forest land by forest type and land class, Minnesota, 1977

(In thousand acres)

\begin{tabular}{lrrrr}
\hline & & & \multicolumn{2}{c}{ Noncommercial } \\
\cline { 3 - 5 } Forest type & $\begin{array}{c}\text { Total } \\
\text { forest }\end{array}$ & Commercial & Unproductive & $\begin{array}{r}\text { Productive- } \\
\text { reserved }\end{array}$ \\
\hline Jack pine & 715.4 & 504.4 & 2.8 & 208.2 \\
Red-white pine & 391.9 & 312.5 & 7.5 & 71.9 \\
Spruce-fir & $1,110.2$ & 938.3 & 67.2 & 104.7 \\
Black spruce & $2,142.9$ & $1,041.8$ & $1,032.4$ & 68.7 \\
Northern white-cedar & 647.2 & 498.6 & 136.0 & 12.6 \\
Tamarack & 642.4 & 465.4 & 173.8 & 3.2 \\
Oak-hickory & $1,005.5$ & 893.9 & 100.2 & 11.4 \\
Elm-ash-cottonwood & 964.0 & 738.1 & 187.6 & 38.3 \\
Maple-basswood & $1,314.6$ & $1,283.9$ & 7.6 & 23.1 \\
Aspen-birch & $7,591.8$ & $6,848.8$ & 109.1 & 633.9 \\
Nonstocked & 183.3 & 169.4 & 1.3 & 2.6 \\
\multicolumn{1}{c}{ All types } & $16,709.2$ & $13,695.1$ & $7,835.5$ & $1,178.6$ \\
\hline
\end{tabular}

\section{APPENDIX}

\section{SURVEY PROCEDURE}

The major steps in determining the areas by land class and forest type were as follows:

1. A total of 276,897 1-acre points were distributed systematically across aerial photos of the entire area, except the-Chippewa and Superior National Forests. These points were classified as either forest land $(72,700)$, unproductive forest land $(4,483)$, nonforest land $(197,674)$, or questionable $(2,040)$, in order to make a preliminary estimate of forest area. Next, all of the forest points (72,700), 592 unproductive forest points, and 2,040 questionable points were stereoclassified as to forest type, stand-size class, and density. Then 9,796 points classed as forest, 592 points classed as unproductive, 276 points classed as questionable, and 25,498 points classified as nonforest were examined on the ground to correct the preliminary area estimate for errors in classification and for actual changes in land use since the photos were taken.

2. Data from the National Forests were incorporated in the Survey data. Area statistics for the
Chippewa and Superior National Forests were prepared by the Forest Timber Management staff from compartment examination records.

3. Data were compiled at the St. Paul office.

\section{COMPARING MINNESOTA'S FOURTH SURVEY WITH THE THIRD SURVEY}

Data from new forest surveys are often compared with data from earlier forest surveys to determine trends in forest areas and volumes. Changes in procedures and definitions between surveys make it necessary to adjust earlier survey data so they are comparable to data from the new survey.

In Minnesota, published 1962 commercial forest area was adjusted to take into account changes in the Unit boundaries between surveys. Then, a portion of the 1962 commercial forest area was withdrawn and added to unproductive forest (noncommercial) and to nonforest to allow for changes in the method of determining land uses. 


\section{DEFINITION OF TERMS}

\section{Land-Use Classes}

Gross area.-The entire area of land and water as determined by the Bureau of Census, 1970 .

Land area.-The area of dry land and land temporarily or partially covered by water such as marshes, swamps, flood plains, streams, sloughs, and estuaries. Canals less than 1/8-mile wide, and lakes, reservoirs, and ponds smaller than 40 acres are included as land area. These figures are from the Bureau of Census, 1970.

Forest land.-Land at least 16.7 percent stocked by forest trees of any size, or forme having such tree cover, and not currently developed or nonforest use. Includes afforested areas. The minimum forest area classified was 1 acre. Roadside, streamside, and shelterbelt strips of timber must have a crown width of at least 120 feet to qualify as forest land. Unimproved roads and trails, streams, and clearings in forest areas were classed as forest if less than 120 feet wide.

Commercial forest lang -Forest land that is producing or is capable of paducing crops of industrial wood and that is not withdrawn from timber utilization by statute or administrative regulation. This includes areas suitable for management to grow crops of industrial wood generally of a site quality capable of producing in excess of 20 cubic feet per acre of annual growth. This includes both inaccessible and inoperable areas.

Noncommercial forest land.-(a) Unproductive--forest land incapable of yielding crops of industrial wood because of adverse site conditions, (b) Productive-reserved-forest land withdrawn from commercal timber use through statute or administrative regulation, or exclusively used for Christmas tree production.

Nonforest land.-Land that has never supported forests, and land formerly forested where forest use is precluded by ảevelopment for nonforest uses, such as cropland, improved pasture, residential areas, and city parks. Alsi includes improved roads and adjoining rights-of-vay, powerlice clearings, and certain areas of wate: classified by the Bureau of Census as land. Unimprived roads, sureams, canals, and nonforest strips $a$ forest areas must be more than 120 feet wide, and clearings in forested areas must be more than 1 acre in size, to qualify as nonforest land.

\section{Ownership Classes}

National Forest.-Federal lands that have been designated by executive order or statute as national forests or purchase units, and other lands under the administration of the USDA Forest Service.

Other federal.-Federal lands other than $\mathrm{Na}$ tional Forest.

State, county, and municipal.-Lands owned by States, counties, or local public agencies, or land leased by them for more than 50 years.

Forest industry.-Lands owned by companies or individuals operating primary wood-using plants.

Farmer-owned.-Lands owned by operators of farms. A farm must include 10 or more acres from which the sale of agricultural products totals $\$ 50$ or more annually, or if less than 10 acres, the yield must be at least $\$ 250$ annually.

Farmer-owned, leased.-Lands owned by operators of farms but leased to another party.

Miscellaneous private-corporation. - Lands owned by a private corporation not in the business of operating primary wood-using plants.

Miscellaneous private-individual. - Lands owned by a private individual.

Miscellaneous private-corporation, leased. Lands owned by a private corporation but leased to another party.

Miscellaneous private-individual, leased. Lands owned by a private individual but leased to another party.

\section{Stand-size Classes}

Stand.-A growth of trees on a minimum of 1 acre of forest land that is stocked by forest trees of any size.

Sawtimber stands.-Stands at least 16.7 percent stocked with growing-stock trees, with half or more of this stocking in sawtimber or poletimber trees and with sawtimber stocking at least equal to poletimber stocking.

Poletimber stands.-Stands at least 16.7 percent stocked with growing-stock trees, and with half or more of this stocking in sawtimber and/or poletimber trees and with poletimber stocking exceeding that of sawtimber. 
Sapling-seedling stands.--Stands at least 16.7 percent stocked with growing-stock trees and with saplings and/or seedlings comprising more than half of this stocking.

Nonstocked areas.-Commercial forest land on which stocking of growing-stock trees is less than 16.7 percent.

\section{Other Classifications}

Site index.-An expression of forest site quality based on the height of a free-growing dominant or codominant tree of a representative species in the forest type at age 50 .

Site class.-A classification of forest land in terms of inherent capacity to grow crops of industrial wood expressed in cubic-foot growth per acre per year.

Stand-age.-Age of the main stand. Main stand refers to trees of the dominant forest type and standsize class.

Basal area.-The area in square feet of the cross section at breast height of a single tree. When the basal area of all the trees in a stand are summed, the result is usually expressed as square feet of basal area per acre.

Owner size-class.-The total number of acres of commercial forest land owned by one individual or agency.

\section{Forest Types}

A classification of forest land based upon the species forming a plurality of live-tree stocking. Major forest types in Minnesota are:

Jack pine.-Forests in which jack pine comprises a plurality of the stocking. (Common associates include eastern white pine, red pine, aspen, birch, and maple.)

Red pine.-Forests in which red pine comprises a plurality of the stocking. (Common associates include eastern white pine, jack pine, aspen, birch, and maple.)

White pine.-Forests in which eastern white pine comprises a plurality of the stocking. (Common associates include red pine, jack pine, aspen, birch, and maple.)
Balsam fir.-Forests in which balsam fir and white spruce comprise a plurality of the stocking with balsam fir the most common. (Common associates include white spruce, aspen, maple, birch, northern white-cedar, and tamarack.)

White spruce.-Forests in which white spruce and balsam fir comprise a plurality of the stocking with white spruce the most common. (Common associates include balsam fir, aspen, maple, birch, northern white-cedar, and tamarack.)

Black spruce.-Forests in which swamp conifers comprise a plurality of the stocking with black spruce the most common. (Common associates include tamarack and northern white-cedar.)

Northern white-cedar.-Forests in which swamp conifers comprise a plurality of the stocking with northern white-cedar the most common. (Common associates include tamarack and black spruce.)

Tamarack.-Forests in which swamp conifers comprise a plurality of the stocking with tamarack the most common. (Common associates include black spruce and northern white-cedar.)

Oak-hickory.-Forests in which northern red oak, white oak, bur oak, and hickory, singly or in combination, comprise a plurality of the stocking. (Common associates elm, maple, and aspen.)

Elm-ash-cottonwood.-Forests in which lowland elm, ash, cottonwood and red maple, singly or in combination, comprise a plurality of the stocking. (Common associates include basswood and balsam poplar.)

Maple-basswood.-Forests in which sugar maple, basswood, yellow birch, upland American elm, and red maple, singly or in combination, comprise a plurality of the stocking. (Common associates include white pine and elm.)

Aspen.-Forests in which quaking aspen and bigtooth aspen, singly or in combination, comprise a plurality of the stocking. (Common associates include balsam poplar, balsam fir, and paper birch.)

Paper birch.-Forests in which paper birch comprises a plurality of the stocking. (Common associates include maple, aspen, and balsam fir.)

Balsam poplar.-Forests in which balsam poplar comprises a plurality of the stocking. (Common associates include aspen, elm, and ash.) 


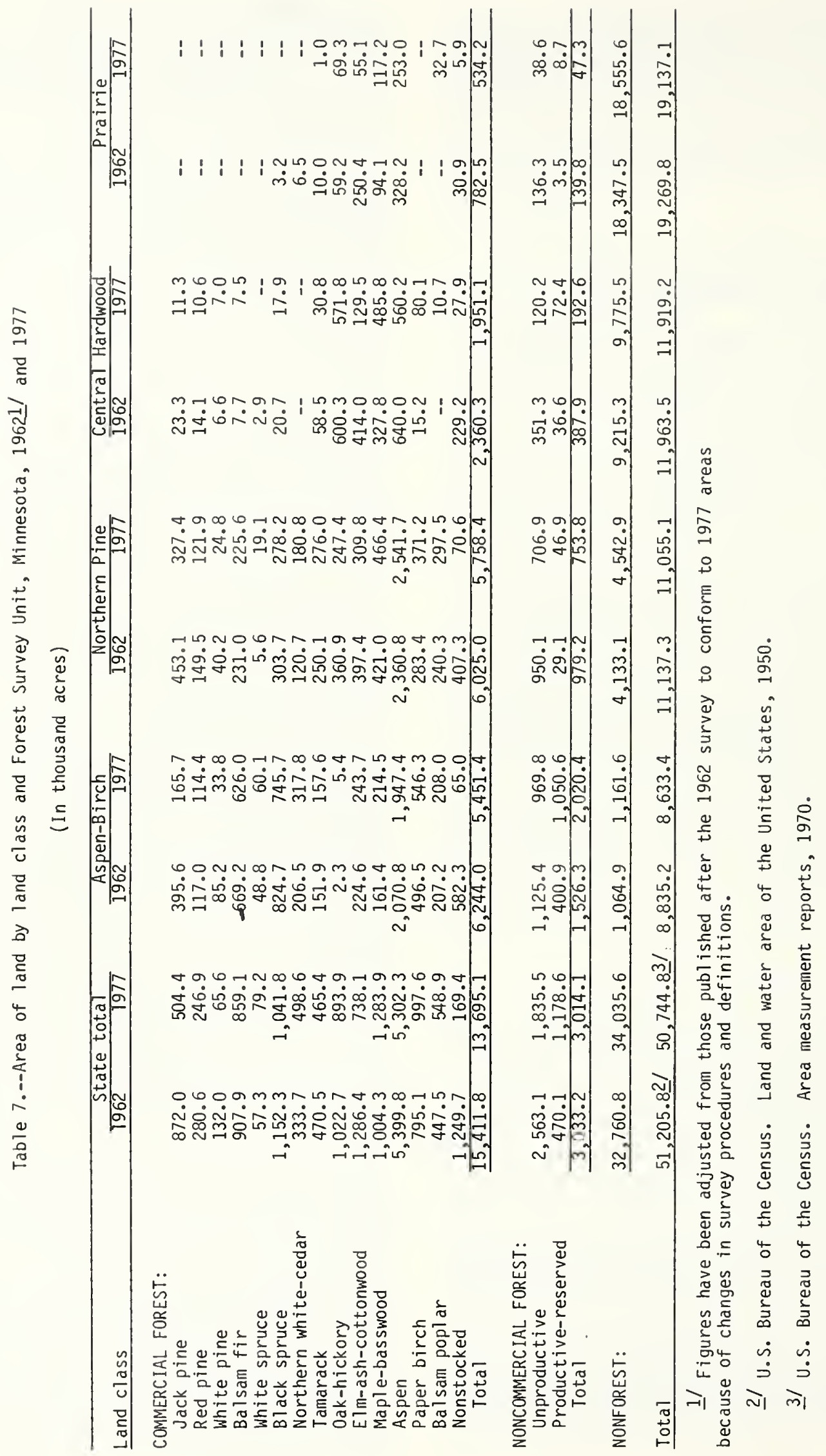


Table 8.--Commercial forest land lost to other land uses between 1962 and 1977

by Forest Survey Unit, Minnesota

(In thousand acres)

\begin{tabular}{|c|c|c|c|c|c|}
\hline Land class & Total & $\begin{array}{l}\text { Aspen- } \\
\text { Birch } \\
\end{array}$ & $\begin{array}{l}\text { Northern } \\
\text { Pine } \\
\end{array}$ & $\begin{array}{l}\text { Central } \\
\text { Hardwood }\end{array}$ & Prairie \\
\hline $\begin{array}{l}\text { NONCOMMERC IAL FOREST: } \\
\text { Productive-reserved } \\
\text { Unproductive } \\
\text { Subtotal }\end{array}$ & $\begin{array}{r}673.1 \\
-- \\
673.1 \\
\end{array}$ & $\begin{array}{r}617.2 \\
-- \\
617.2 \\
\end{array}$ & $\begin{array}{r}16.9 \\
-- \\
16.9 \\
\end{array}$ & $\begin{array}{r}34.0 \\
-- \\
34.0 \\
\end{array}$ & $\begin{array}{r}5.0 \\
-- \\
5.0 \\
\end{array}$ \\
\hline $\begin{array}{l}\text { NONFOREST: } \\
\text { Cropland } \\
\text { Improved pasture } \\
\text { Wooded pasture } \\
\text { Wooded strips } \\
\text { Marsh } \\
\text { Other farm } \\
\text { Urban and other } \\
\text { Noncensus water } \\
\text { Subtotal }\end{array}$ & $\begin{array}{r}355.8 \\
127.4 \\
16.4 \\
6.3 \\
53.6 \\
23.4 \\
405.6 \\
53.7 \\
1,042.2 \\
\end{array}$ & $\begin{array}{c}-- \\
34.0 \\
-- \\
6.3 \\
20.9 \\
-- \\
62.3 \\
51.9 \\
175.4 \\
\end{array}$ & $\begin{array}{c}55.4 \\
42.2 \\
13.3 \\
-- \\
16.7 \\
13.3 \\
108.8 \\
-- \\
249.7 \\
\end{array}$ & $\begin{array}{r}87.5 \\
44.2 \\
3.1 \\
-- \\
16.0 \\
2.4 \\
222.0 \\
-- \\
375.2 \\
\end{array}$ & $\begin{array}{r}212.9 \\
7.0 \\
-- \\
-- \\
-- \\
7.7 \\
12.5 \\
1.8 \\
241.9 \\
\end{array}$ \\
\hline $\begin{array}{l}\text { CENSUS WATER: } \\
\text { Total }\end{array}$ & $\begin{array}{r}1.4 \\
1,716.7 \\
\end{array}$ & $\begin{array}{r}-- \\
792.6 \\
\end{array}$ & $\frac{--}{266.6}$ & $\begin{array}{r}-- \\
409.2 \\
\end{array}$ & $\begin{array}{r}1.4 \\
248.3 \\
\end{array}$ \\
\hline
\end{tabular}


Table 9.--Area by land class and Forest Survey Unit, Minnesota, 1977

(In thousand acres)

\begin{tabular}{|c|c|c|c|c|c|}
\hline $\begin{array}{l}\text { Land } \\
\text { class }\end{array}$ & $\begin{array}{c}\text { All } \\
\text { units }\end{array}$ & $\begin{array}{l}\text { Aspen- } \\
\text { Birch }\end{array}$ & $\begin{array}{l}\text { Northern } \\
\text { Pine }\end{array}$ & $\begin{array}{l}\text { Central } \\
\text { Hardwood }\end{array}$ & Prairie \\
\hline $\begin{array}{l}\text { FOREST: } \\
\text { Commercial } \\
\text { Productive-reserved } 1 / \\
\text { Unproductive } \\
\text { Total }\end{array}$ & $\begin{array}{r}13,695.1 \\
1,178.6 \\
1,835.5 \\
16,709.2 \\
\end{array}$ & $\begin{array}{r}5,451.4 \\
1,050.6 \\
969.8 \\
7,471.8 \\
\end{array}$ & $\begin{array}{r}5,758.4 \\
46.9 \\
706.9 \\
6,512.2 \\
\end{array}$ & $\begin{array}{r}1,951.1 \\
72.4 \\
120.2 \\
2,143.7 \\
\end{array}$ & $\begin{array}{r}534.2 \\
8.7 \\
38.6 \\
581.5 \\
\end{array}$ \\
\hline $\begin{array}{l}\text { NONFORESI: } \\
\text { Nonforest with trees: } \\
\text { Cropland with trees } \\
\text { Improved pasture with trees } \\
\text { Wooded strips } \\
\text { Idle farmland with trees } \\
\text { Windbreaks } \\
\text { Wooded pasture } \\
\text { Subtotal }\end{array}$ & $\begin{array}{r}65.7 \\
90.1 \\
158.9 \\
7.9 \\
151.0 \\
135.0 \\
608.6\end{array}$ & $\begin{array}{r}-. \\
4.8 \\
10.6 \\
1.6 \\
13.5 \\
23.3 \\
53.8\end{array}$ & $\begin{array}{r}20.8 \\
29.4 \\
24.6 \\
1.4 \\
12.3 \\
22.1 \\
110.6\end{array}$ & $\begin{array}{r}35.4 \\
50.0 \\
99.4 \\
3.9 \\
103.1 \\
80.5 \\
372.3\end{array}$ & $\begin{array}{r}9.5 \\
5.9 \\
24.3 \\
1.0 \\
22.1 \\
9.1 \\
71.9\end{array}$ \\
\hline $\begin{array}{l}\text { Nonforest without trees: } \\
\text { Cropland without trees } \\
\text { Improved pasture without trees } \\
\text { Idle farmland without trees } \\
\text { Marsh } \\
\text { Other farm-farmstead } \\
\text { Urban and other } \\
\text { Noncensus water } \\
\text { Subtotal } \\
\text { Total }\end{array}$ & $\begin{array}{r}26,421.3 \\
897.7 \\
47.1 \\
2,961.6 \\
570.5 \\
2,406.7 \\
122.1 \\
33,427.0 \\
34,035.6 \\
\end{array}$ & $\begin{array}{r}357.1 \\
67.6 \\
15.4 \\
350.6 \\
33.6 \\
283.5 \\
--- \\
1,107.8 \\
1,161.6 \\
\end{array}$ & $\begin{array}{r}2,007.2 \\
527.3 \\
22.3 \\
1,449.9 \\
43.3 \\
350.2 \\
32.1 \\
4,432.3 \\
4,542.9 \\
\end{array}$ & $\begin{array}{r}7,218.5 \\
159.5 \\
5.8 \\
662.5 \\
219.0 \\
1,085.7 \\
52.2 \\
9,403.2 \\
9,775.5 \\
\end{array}$ & $\begin{array}{r}16,838.5 \\
143.3 \\
3.6 \\
498.6 \\
274.6 \\
687.3 \\
37.8 \\
18,483.7 \\
18,555.6 \\
\end{array}$ \\
\hline Total $2 /$ & $50,744.8$ & $8,633.4$ & $11,055.1$ & $11,919.2$ & $19,137.1$ \\
\hline CENSUS WATER: & $3,058.7$ & 715.1 & $1,437.7$ & 581.9 & 324.0 \\
\hline Total gross area & $53,803.5$ & $9,348.5$ & $12,492.8$ & $12,501.1$ & $19,461.1$ \\
\hline
\end{tabular}

1/Includes 3,000 acres of productive-deferred forest land, commercial forest land being withheld from harvest while a decision is made whether to place it in productive-reserved status.

2/U.S. Department of Commerce, Bureau of Census. 1970. Area measurement reports, GE-20 No. 1, 22 p. 
Table 10.--Area of 1 and and forest land by county, Minnesota, 1977

\begin{tabular}{|c|c|c|c|c|c|}
\hline \multirow[b]{3}{*}{ County } & \multicolumn{4}{|c|}{ ASPEN-BIRCH } & \multirow{3}{*}{$\begin{array}{c}\text { Percent } \\
\text { commercial } \\
\text { forest }\end{array}$} \\
\hline & \multirow[b]{2}{*}{$\begin{array}{l}\text { Land } 1 / \\
\text { area }\end{array}$} & \multicolumn{3}{|c|}{ Forest land } & \\
\hline & & $\begin{array}{l}\text { Al1 } \\
\text { forest }\end{array}$ & \multicolumn{2}{|c|}{ Non- } & \\
\hline & $--\cdot$ & - - -Tho & nd acres- - & ---- & Percent \\
\hline Carlton & 551.8 & 336.1 & 23.3 & 312.8 & 57 \\
\hline Cook & 861.4 & 852.9 & 314.1 & 538.8 & 63 \\
\hline Koochiching & $2,001.3$ & $1,794.3$ & 515.4 & $1,278.9$ & 64 \\
\hline Lake & $1,319.8$ & $1,257.1$ & 401.8 & 855.3 & 65 \\
\hline St. Louis & $3,899.1$ & $3,231.4$ & 765.8 & $2,465.6$ & 63 \\
\hline Total & $8,633.4$ & $7,471.8$ & $2,020.4$ & $5,451.4$ & 63 \\
\hline \multicolumn{6}{|c|}{ NORTHERN PINE } \\
\hline Aitkin & $1,169.7$ & 762.6 & 90.1 & 672.5 & 58 \\
\hline Becker & 830.0 & 322.8 & 8.9 & 313.9 & 38 \\
\hline Beltrami & $1,604.2$ & $1,044.0$ & 249.4 & 794.6 & 50 \\
\hline Cass & $1,278.8$ & 883.4 & 24.8 & 858.6 & 67 \\
\hline Clearwater & 639.9 & 333.7 & 32.0 & 301.7 & 47 \\
\hline Crow Wing & 636.5 & 380.7 & 8.8 & 371.9 & 58 \\
\hline Hubbard & 596.2 & 403.2 & 5.2 & 398.0 & 67 \\
\hline Itasca & $1,685.3$ & $1,331.6$ & 50.6 & $1,281.0$ & 76 \\
\hline Lake of the Woods & 838.8 & 596.1 & 235.5 & 360.6 & 43 \\
\hline Mahnomen & 360.2 & 107.8 & 1.4 & 106.4 & 30 \\
\hline Roseau & $1,072.8$ & 232.6 & 40.7 & 191.9 & 18 \\
\hline Wadena & 342.7 & 113.7 & 6.4 & 107.3 & 31 \\
\hline Total & $11,055.1$ & $6,512.2$ & 753.8 & $5,758.4$ & 52 \\
\hline \multicolumn{6}{|c|}{ CENTRAL HARDWOODS } \\
\hline Anoka & 271.0 & 42.9 & 6.3 & 36.6 & 14 \\
\hline Benton & 257.4 & 28.3 & 2.2 & 26.1 & 10 \\
\hline Carver & 229.9 & 12.3 & 1.9 & 10.4 & 5 \\
\hline Chisago & 268.1 & 55.7 & 5.5 & 50.2 & 19 \\
\hline Dakota & 368.4 & 19.5 & 3.0 & 16.5 & 5 \\
\hline Dougl as & 413.9 & 20.4 & 1.9 & 18.5 & 5 \\
\hline Filimore & 549.8 & 72.9 & 7.6 & 65.3 & 12 \\
\hline Goodhue & 482.1 & 60.7 & 4.3 & 56.4 & 12 \\
\hline Hennepin & 363.1 & 11.4 & 3.6 & 7.8 & 2 \\
\hline Houston & 361.4 & 119.6 & 8.1 & 111.5 & 31 \\
\hline Isant $i$ & 280.6 & 54.1 & 7.2 & 46.9 & 17 \\
\hline Kanabec & 335.1 & 134.5 & 5.5 & 129.0 & 39 \\
\hline LeSueur & 281.6 & 11.4 & 1.4 & 10.0 & 4 \\
\hline Mille Lacs & 365.6 & 136.2 & 13.4 & 122.8 & 34 \\
\hline Morrison & 721.4 & 161.3 & 12.6 & 148.7 & 21 \\
\hline $01 m s t e d$ & 419.6 & 35.3 & 3.3 & 32.0 & 8 \\
\hline Otter Tail & $1,256.2$ & 200.5 & 14.2 & 186.3 & 15 \\
\hline Pine & 904.7 & 477.6 & 52.0 & 425.6 & 47 \\
\hline Ramsey & 99.0 & 0.1 & 0.1 & -- & 0 \\
\hline Rice & 317.6 & 14.1 & 2.0 & 12.1 & 4 \\
\hline Scott & 225.7 & 16.3 & 2.7 & 13.6 & 6 \\
\hline Sherburne & 275.8 & 62.3 & 5.4 & 56.9 & 21 \\
\hline Stearns & 858.9 & 60.3 & 4.3 & 56.0 & 7 \\
\hline Todd & 602.6 & 111.1 & 6.6 & 104.5 & 17 \\
\hline Wabasha & 334.1 & 62.1 & 4.7 & 57.4 & 17 \\
\hline Washington & 246.9 & 12.1 & 1.9 & 10.2 & 4 \\
\hline Winona & 397.1 & 114.9 & 8.6 & 106.3 & 27 \\
\hline Wright & 431.6 & 35.8 & 2.3 & 33.5 & 8 \\
\hline Total & $11,919.2$ & $2,143.7$ & 192.6 &, 951.1 & 16 \\
\hline
\end{tabular}




\begin{tabular}{|c|c|c|c|c|c|}
\hline County & $\begin{array}{l}\text { Land } 1 / \\
\text { area- }\end{array}$ & $\begin{array}{c}\text { AlT } \\
\text { forest }\end{array}$ & $\begin{array}{c}\text { Forest la } \\
\text { Non- } \\
\text { commercial }\end{array}$ & Commercial & $\begin{array}{c}\text { Percent } \\
\text { commercial } \\
\text { forest }\end{array}$ \\
\hline & --- & - - -Tho & and acres- - & $-\cdots-$ & Percent \\
\hline Big Stone & 313.8 & 2.7 & 0.3 & 2.4 & 1 \\
\hline Blue Earth & 471.3 & 23.6 & 2.2 & 21.4 & 5 \\
\hline Brown & 390.3 & 10.7 & 1.6 & 9.1 & 2 \\
\hline Chippewa & 372.2 & 4.0 & 0.1 & 3.9 & 1 \\
\hline Clay & 669.1 & 11.2 & 0.9 & 10.3 & 2 \\
\hline Cottonwood & 407.0 & 2.6 & 0.1 & 2.5 & 1 \\
\hline Dodge & 278.4 & 7.4 & 1.0 & 6.4 & 2 \\
\hline Faribault & 455.1 & 6.5 & 0.3 & 6.2 & 1 \\
\hline Freeborn & 448.4 & 5.7 & 0.9 & 4.8 & 1 \\
\hline Grant & 349.6 & 3.0 & 0.1 & 2.9 & 1 \\
\hline Jackson & 445.5 & 2.3 & 0.2 & 2.1 & 1 \\
\hline Kandiyohi & 501.2 & 12.4 & 2.5 & 9.9 & 2 \\
\hline Kittson & 719.0 & 71.9 & 4.4 & 67.5 & 9 \\
\hline Lac qui Parle & 491.6 & 5.2 & 0.6 & 4.6 & 1 \\
\hline Lincoln & 339.8 & 2.2 & 0.2 & 2.0 & 1 \\
\hline Lyon & 453.5 & 5.3 & 0.9 & 4.4 & 1 \\
\hline McLeod & 312.3 & 6.1 & 0.3 & 5.8 & 2 \\
\hline Marshall & $1,145.1$ & 142.7 & 14.2 & 128.5 & $1 \overline{1}$ \\
\hline Martin & 450.1 & 3.8 & 0.2 & 3.6 & 1 \\
\hline Meeker & 396.3 & 12.0 & 1.2 & 10.8 & 3 \\
\hline Mower & 449.9 & 6.1 & 0.9 & 5.2 & 1 \\
\hline Murray & 449.9 & 1.4 & 0.3 & 1.1 & -- \\
\hline Nicollet & 276.7 & 13.7 & 1.4 & 12.3 & 4 \\
\hline Nobles & 455.5 & 0.7 & -- & 0.7 & -- \\
\hline Norman & 566.4 & 23.1 & 0.9 & 22.2 & 4 \\
\hline Pennington & 398.0 & 32.0 & 1.3 & 30.7 & 8 \\
\hline Pipestone & 297.0 & 0.4 & $=$ & 0.4 & -- \\
\hline Polk & $1,288.1$ & 71.3 & 3.3 & 68.0 & 5 \\
\hline Pope & 428.3 & 7.8 & 0.9 & 6.9 & 2 \\
\hline Red Lake & 276.5 & 28.9 & 1.7 & 27.2 & 10 \\
\hline Redwood & 559.4 & 6.7 & 0.5 & 6.2 & 1 \\
\hline Renville & 626.3 & 8.0 & 0.8 & 7.2 & 1 \\
\hline Rock & 310.4 & 0.5 & - & 0.5 & -- \\
\hline Sibley & 373.2 & 11.9 & 1.0 & 10.9 & 3 \\
\hline Steele & 272.3 & 5. 6 & 0.6 & 5.0 & 2 \\
\hline Stevens & 357.2 & 1.0 & - & 1.0 & -- \\
\hline Swift & 473.2 & 5.0 & 0.3 & 4.7 & 1 \\
\hline Traverse & 363.7 & 0.9 & -- & 0.9 & -- \\
\hline Waseca & 265.3 & 5.0 & 0.4 & 4.6 & 2 \\
\hline Watonwan & 276.9 & 1.1 & -- & 1.1 & -- \\
\hline Wilkin & 481.1 & 0.5 & -- & 0.5 & - \\
\hline Yellow Medicine & 482.2 & 8.6 & 0.8 & 7.8 & 2 \\
\hline Total & $19,137.1$ & 581.5 & 47.3 & 534.2 & 3 \\
\hline All Units & $50,744.8$ & $16,709.2$ & $3,014.1$ & $13,695.1$ & 27 \\
\hline
\end{tabular}

$1 /$ U.S. Department of Commerce, Bureau of Census. 1970. Area measurement reports, GE-20 No. 1,22 . 
Table 11.--Area of commercial forest land by ownership

class and Forest Survey Unit, Minnesota, 1977

(In thousand acres)

\begin{tabular}{|c|c|c|c|c|c|}
\hline Ownership class & $\begin{array}{c}\text { All } \\
\text { units }\end{array}$ & $\begin{array}{l}\text { Aspen- } \\
\text { Birch }\end{array}$ & $\begin{array}{l}\text { Northern } \\
\text { Pine }\end{array}$ & $\begin{array}{l}\text { Central } \\
\text { Hardwood }\end{array}$ & Prairie \\
\hline National Forest & $1,715.1$ & $1,152.8$ & 562.3 & -- & - \\
\hline Bureau of Land Mgmt. & 43.9 & 8.1 & 35.8 & -- & - \\
\hline Indian & 466.8 & 97.5 & 364.9 & 4.4 & -- \\
\hline Miscellaneous federal & 110.5 & 20.7 & 60.5 & 20.3 & 9.0 \\
\hline State & $2,650.5$ & $1,132.1$ & $1,228.7$ & 244.7 & 45.0 \\
\hline County and municipal & $2,341.6$ & $1,185.9$ & $1,096.7$ & 59.0 & - \\
\hline Forest industry & 772.0 & 534.7 & 233.8 & 0.5 & 3.0 \\
\hline Farmer & $3,403.7$ & 544.2 & $1,322.1$ & $1,141.4$ & 396.0 \\
\hline Farmer owned-leased & -- & -- & & - & - \\
\hline Misc. private-corp. & 466.7 & 246.8 & 154.3 & 61.1 & 4.5 \\
\hline Misc. private-indiv. & $1,712.0$ & 523.6 & 696.6 & 418.1 & 73.7 \\
\hline Misc. priv.-corp., leased & 5.7 & 4.0 & -- & -- & 1.7 \\
\hline Misc. priv.-indiv., leased & 6.6 & 1.0 & 2.7 & 1.6 & 1.3 \\
\hline All owners & $13,695.1$ & $5,451.4$ & $5,758.4$ & $1,951.1$ & 534.2 \\
\hline
\end{tabular}


Table 12.--Area of commercial forest land by ownership class and forest type, Minnesota, 1977

(In thousand acres)

\begin{tabular}{|c|c|c|c|c|c|c|c|c|}
\hline \multirow[b]{2}{*}{ Ownership class } & \multirow[b]{2}{*}{$\begin{array}{c}\text { A11 } \\
\text { types }\end{array}$} & \multicolumn{7}{|c|}{ Forest type } \\
\hline & & $\begin{array}{l}\text { Jack } \\
\text { pine }\end{array}$ & $\begin{array}{l}\text { Red } \\
\text { pine }\end{array}$ & $\begin{array}{l}\text { White } \\
\text { pine }\end{array}$ & $\begin{array}{l}\text { Bal sam } \\
\text { fir }\end{array}$ & $\begin{array}{l}\text { White } \\
\text { spruce }\end{array}$ & $\begin{array}{l}\text { Bl ack } \\
\text { spruce }\end{array}$ & $\begin{array}{l}\text { Northern } \\
\text { white- } \\
\text { cedar }\end{array}$ \\
\hline National Forest & $1,715.1$ & 116.9 & 130.7 & 19.4 & 185.9 & 26.3 & 184.4 & 61.5 \\
\hline Bureau of Land Mgmt. & 43.9 & 6.7 & 1.4 & 1.4 & -- & 1.4 & 6.9 & 6.2 \\
\hline Indian & 466.8 & 5.2 & 8.8 & 7.5 & 23.0 & 6.5 & 51.4 & 48.7 \\
\hline Miscellaneous federal & 110.5 & 5.4 & 1.3 & -- & 6.1 & -- & 4.2 & 1.6 \\
\hline State & $2,650.5$ & 93.8 & 23.7 & 2.6 & 198.7 & 22.3 & 421.2 & 202.0 \\
\hline County and municipal & $2,341.6$ & 82.4 & 24.5 & 4.4 & 196.4 & 4.1 & 160.6 & 68.7 \\
\hline Forest industry & 772.0 & 52.4 & 13.5 & 5.1 & 80.6 & 2.7 & 66.8 & 49.9 \\
\hline Farmer & $3,403.7$ & 80.9 & 21.5 & 16.7 & 75.5 & 7.8 & 69.9 & 25.4 \\
\hline Farmer owned-leased & & -- & -- & -- & -- & -- & & -- \\
\hline Misc. private-corp. & 466.7 & 12.4 & 3.6 & 1.0 & 32.4 & -- & 27.2 & 6.6 \\
\hline Misc. private-indiv. & $1,712.0$ & 48.3 & 17.9 & 7.5 & 60.5 & 8.1 & 49.2 & 28.0 \\
\hline Misc. priv.-corp., leased & 5.7 & -- & -- & -- & -- & -- & - & -- \\
\hline Misc. priv.-indiv., leased & 6.6 & -- & -- & -- & -- & - & -- & -- \\
\hline All owners & $13,695.1$ & 504.4 & 246.9 & 65.6 & 859.1 & 79.2 & $1,041.8$ & 498.6 \\
\hline
\end{tabular}

(Table 12 continued)

Ownership class

\section{National Forest}

Bureau of Land Mgmt.

Indian

Miscellaneous federal

State

County and municipal

Forest industry

Farmer

Farmer owned-l eased

Misc. private-corp.

Misc. private-indiv.

Misc. priv.-corp., leased

Misc. priv.-indiv., leased

A11 owners

498.6 
Table 13.--Area of commercial forest land by ownership class and site class, Minnesota, 1977

(In thousand acres)

\begin{tabular}{|c|c|c|c|c|c|c|c|}
\hline \multirow[b]{2}{*}{ Ownership class } & \multirow[b]{2}{*}{$\begin{array}{c}\text { All } \\
\text { classes } \\
\end{array}$} & \multicolumn{6}{|c|}{ Site class (cubic feet of growth/acre/year) } \\
\hline & & $\begin{array}{c}225 \text { or } \\
\text { more }\end{array}$ & $165-224$ & $120-164$ & $85-119$ & $50-84$ & $20-49$ \\
\hline National Forest & $1,715.1$ & -- & -- & 1.5 & 177.3 & 694.5 & 841.8 \\
\hline Bureau of Land Mgmt. & 43.9 & -- & -- & -- & 4.2 & 14.9 & 24.8 \\
\hline Indian & 466.8 & -- & 1.4 & 8.7 & 78.1 & 151.0 & 227.6 \\
\hline Miscellaneous federal & 110.5 & -- & - & -- & 5.8 & 48.3 & 56.4 \\
\hline State & $2,650.5$ & -- & 1.4 & 31.5 & 374.4 & 722.4 & $1,520.8$ \\
\hline County and municipal & $2,341.6$ & -- & 1.3 & 46.8 & 468.7 & 919.5 & 905.3 \\
\hline Forest industry & 772.0 & -- & 1.2 & 17.5 & 164.8 & 230.5 & 358.0 \\
\hline Farmer & $3,403.7$ & -- & 1.4 & 30.7 & 414.1 & $1,318.3$ & $1,639.2$ \\
\hline Farmer owned-leased & -- & -- & - & -- & -- & -- & -- \\
\hline Misc. private-corp. & 466.7 & -- & -- & 5.2 & 89.0 & 201.4 & 171.1 \\
\hline Misc. private-indiv. & $1,712.0$ & -- & -- & 17.7 & 265.5 & 691.1 & 737.7 \\
\hline Misc. priv.-corp., leased & 5.7 & -- & -- & -- & 1.4 & 4.3 & -- \\
\hline Misc. priv.-indiv., leased & 6.6 & -- & -- & -- & 1.0 & 2.7 & 2.9 \\
\hline All owners & $13,695.1$ & -- & 6.7 & 159.6 & $2,044.3$ & $4,998.9$ & $6,485.6$ \\
\hline
\end{tabular}

lable 14.--Area of commercial forest land by ownership class and size of owner, Minnesota, 1977

(In thousand acres)

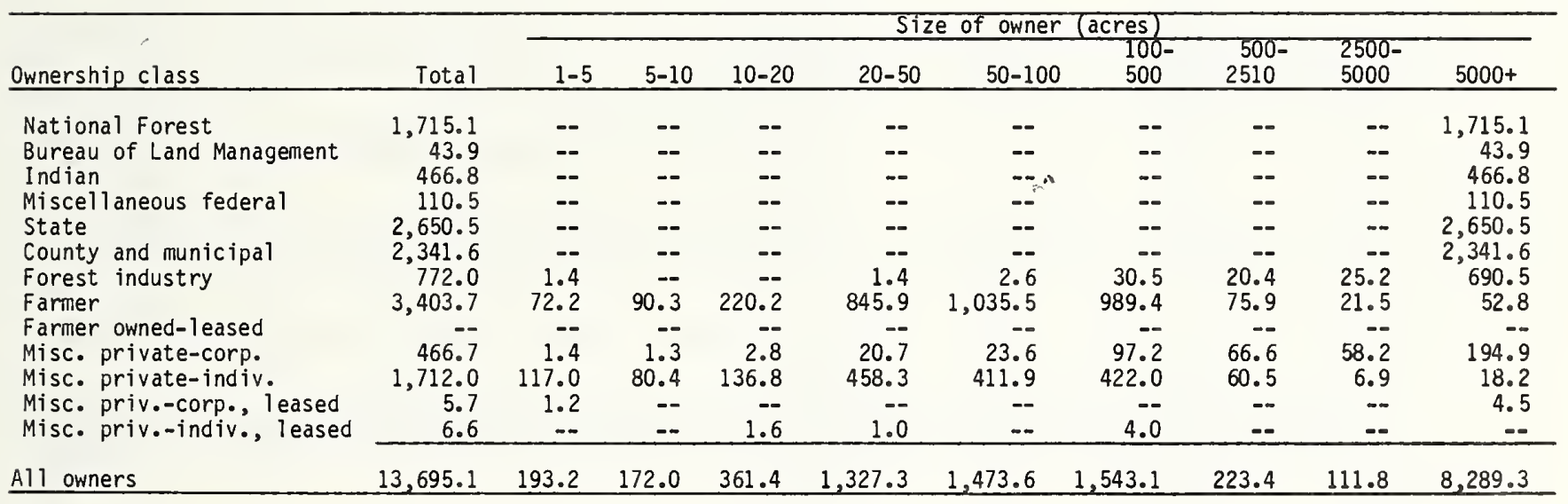




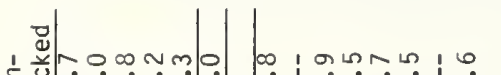
은

言党新

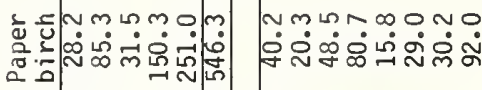

- 10000

ปे

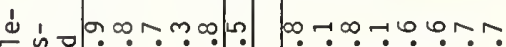

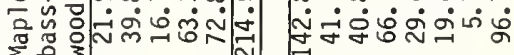

¿. no-mol

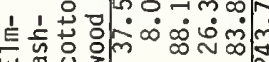

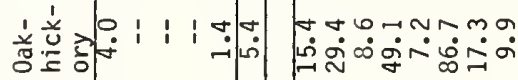

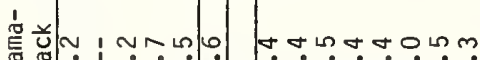

돈

落 을

× كّل

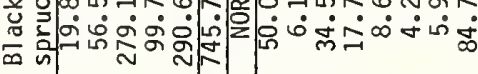

ه ్ㅣㄹ

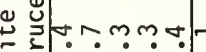

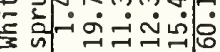

E

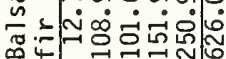

壳

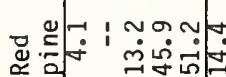

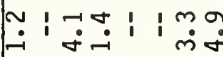

NLMa

ڤீ웜ํ்

ก.:.

-i

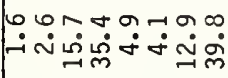

$\sin 20$

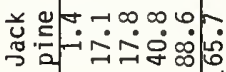

₹

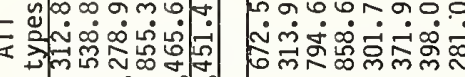

:

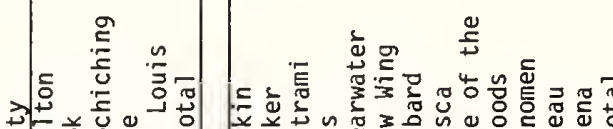

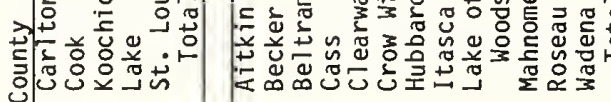
ம்

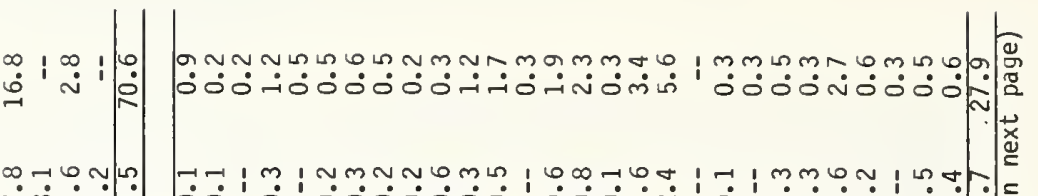

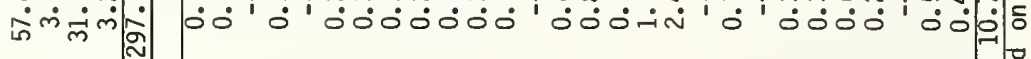

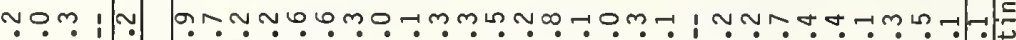
வ்-

- . N ம்

! 0 N ப்

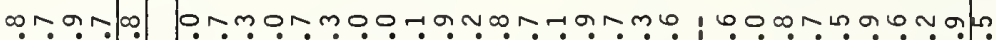

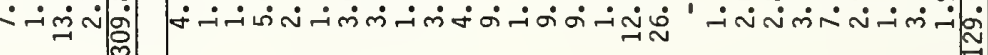

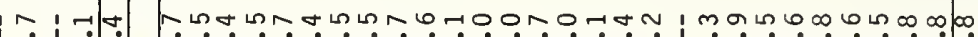

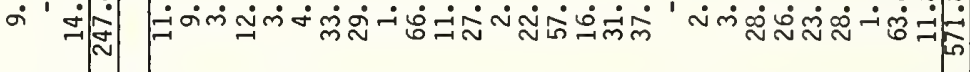
o 0 o mंNin

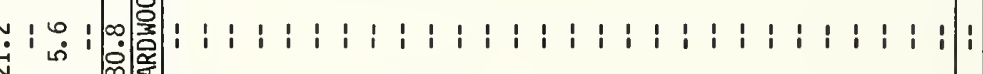
: 1 c

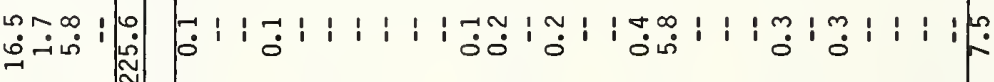

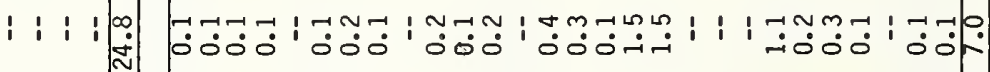
• 1 l

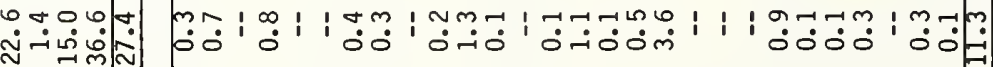
ச্ল

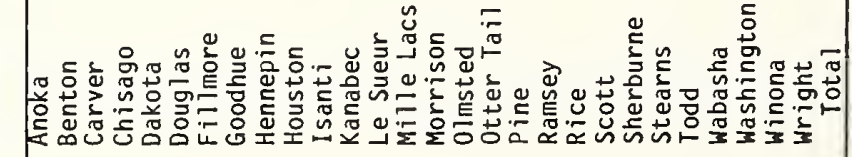




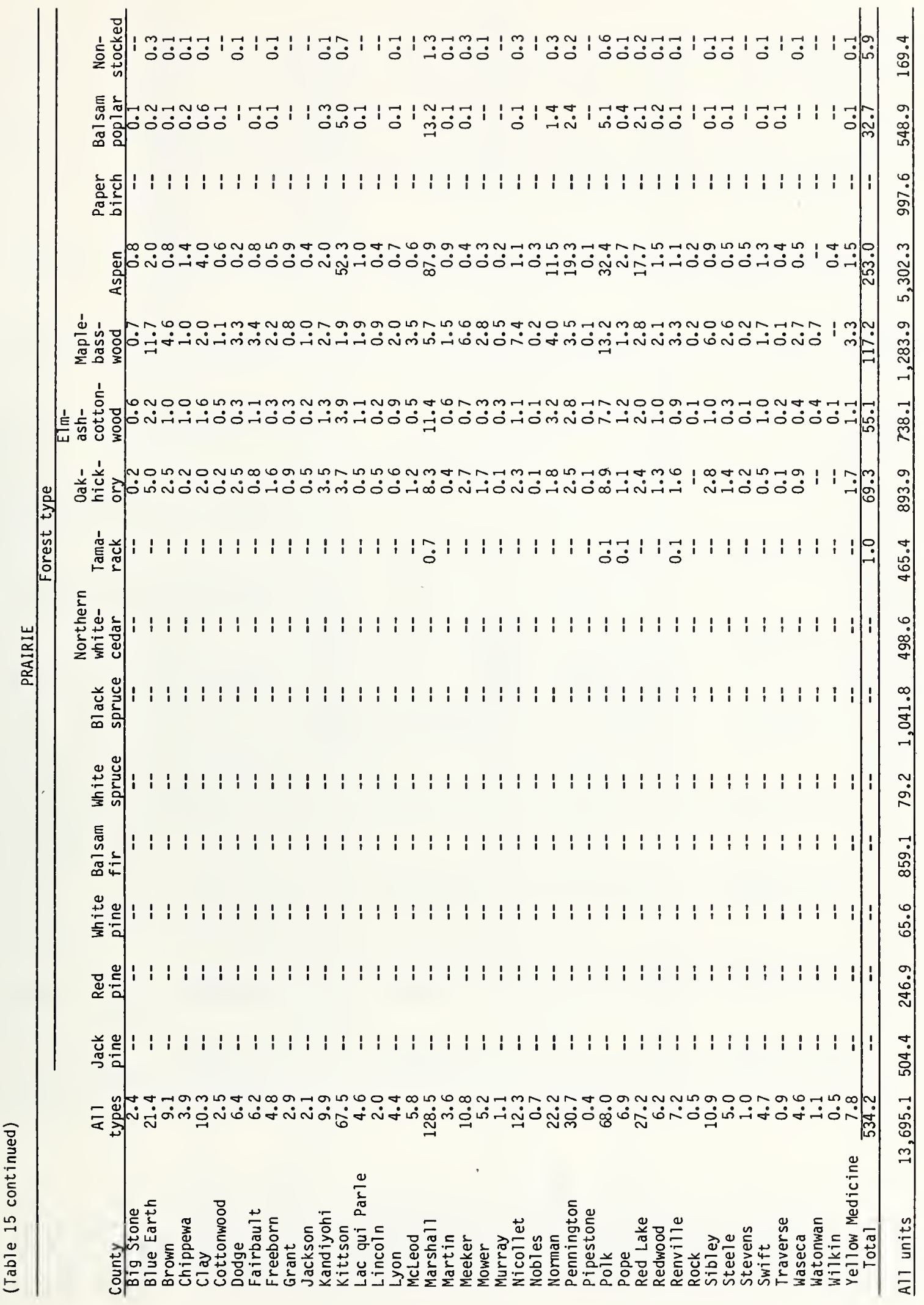




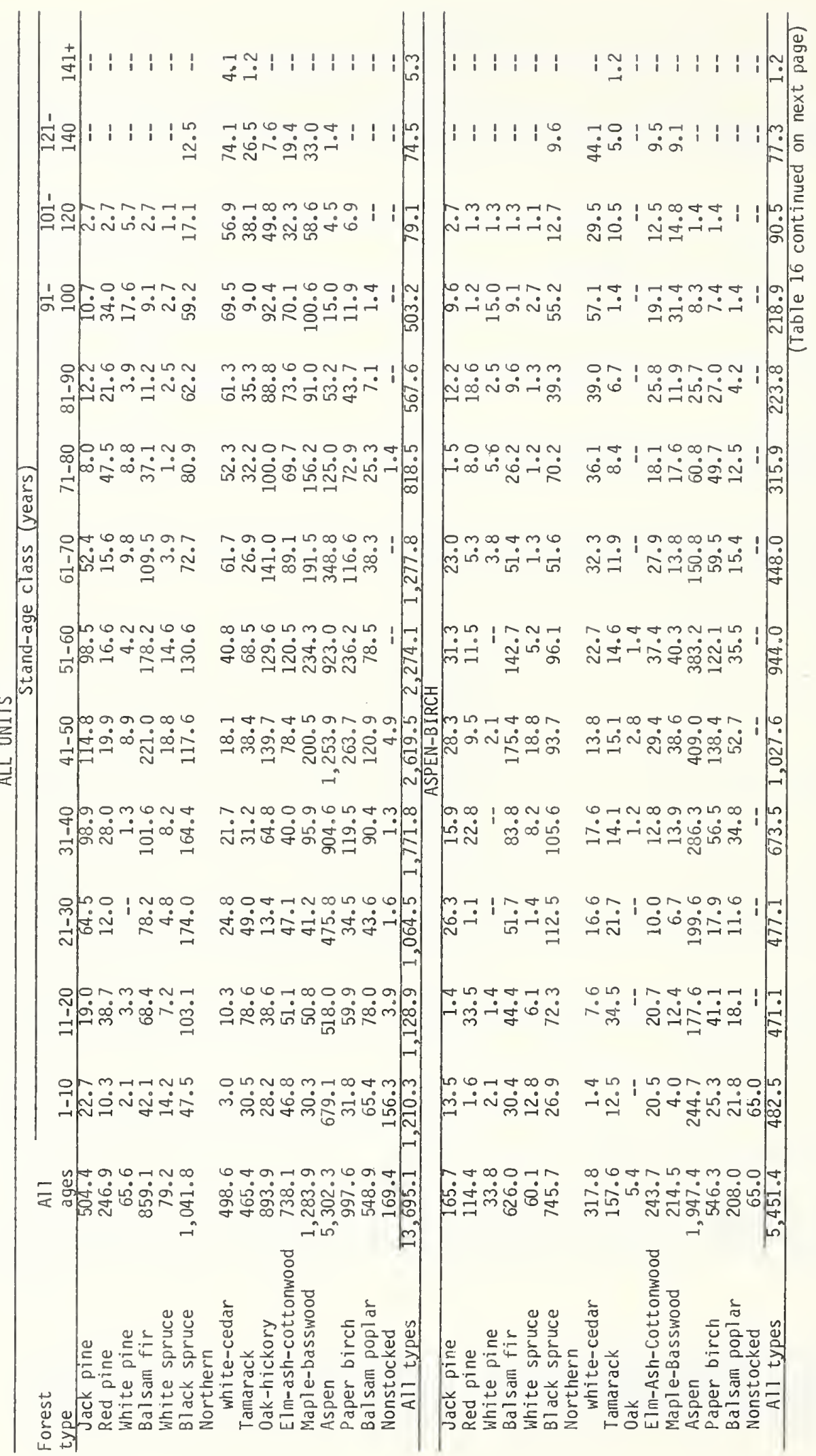




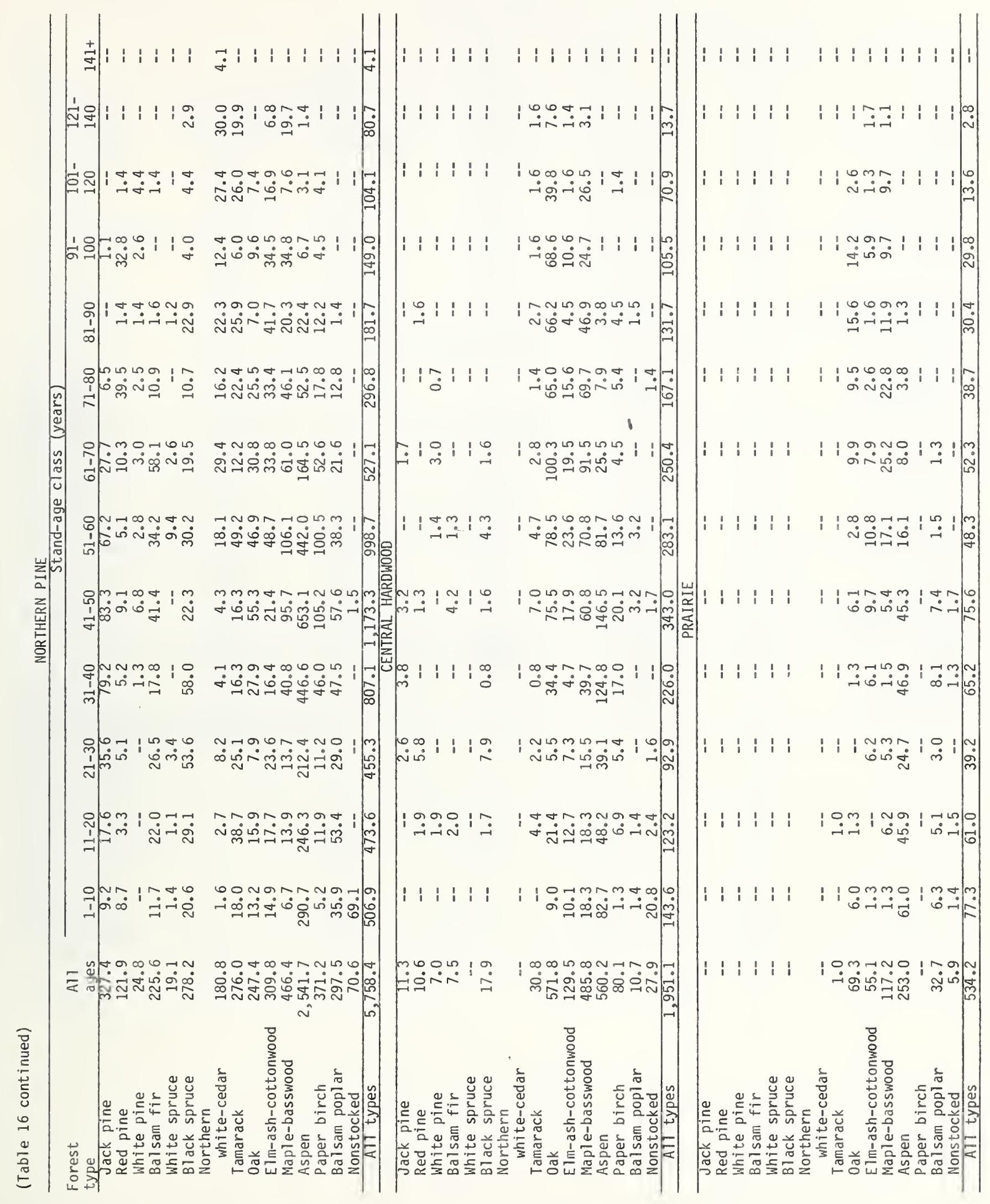


Table 17.--Area of commercial forest land by forest type, Forest Survey Unit, and stand-size class, Minnesota, 1977

(In thousand acres)

ALL UNITS

\begin{tabular}{|c|c|c|c|c|c|}
\hline \multirow{3}{*}{$\begin{array}{l}\text { Forest } \\
\text { type }\end{array}$} & \multirow{3}{*}{$\begin{array}{c}\text { All } \\
\text { stands }\end{array}$} & \multicolumn{4}{|c|}{ Stand-size class } \\
\hline & & $\begin{array}{l}\text { Sawt imber } \\
\text { stands }\end{array}$ & $\begin{array}{l}\text { Poletimber } \\
\text { stands }\end{array}$ & $\begin{array}{l}\text { Sapling and } \\
\text { seedling stands }\end{array}$ & $\begin{array}{l}\text { Nonstocked } \\
\text { areas }\end{array}$ \\
\hline & & $\frac{\text { stands }}{177.3}$ & $\begin{array}{r}\text { stands } \\
247.2\end{array}$ & seedling stands & areas \\
\hline Jack pine & 504.4 & 177.3 & 247.2 & 79.9 & -- \\
\hline Red pine & 246.9 & 145.1 & 41.8 & 60.0 & -- \\
\hline White pine & 65.6 & 58.4 & 3.9 & 3.3 & -- \\
\hline Balsam fir & 859.1 & 140.0 & 490.5 & 228.6 & -- \\
\hline White spruce & 79.2 & 21.7 & 23.5 & 34.0 & -- \\
\hline Black spruce & $1,041.8$ & 31.1 & 390.3 & 620.4 & -- \\
\hline Northern white-cedar & 498.6 & 145.5 & 275.5 & 77.6 & -- \\
\hline Tamarack & 465.4 & 43.5 & 200.3 & 221.6 & -- \\
\hline 0ak-hickory & 893.9 & 452.7 & 360.9 & 80.3 & -- \\
\hline Elm-ash-cottonwood & 738.1 & 194.8 & 388.8 & 154.5 & -- \\
\hline Maple-basswood & $1,283.9$ & 675.6 & 493.5 & 114.8 & -- \\
\hline Aspen & $5,302.3$ & 791.4 & $3,032.3$ & $1,478.6$ & -- \\
\hline Paper birch & 997.6 & 142.0 & 758.6 & 97.0 & -- \\
\hline Balsam poplar & 548.9 & 115.7 & 249.0 & 184.2 & -- \\
\hline Nonstocked & 169.4 & -- & -- & -- & 169.4 \\
\hline All types & $13,695.1$ & $3,134.8$ & $6,956.1$ & $3,434.8$ & 169.4 \\
\hline \multicolumn{6}{|c|}{ ASPEN-BIRCH } \\
\hline Jack pine & 165.7 & 68.3 & 66.3 & 31.1 & -- \\
\hline Red pine & 114.4 & 49.2 & 19.9 & 45.3 & -- \\
\hline White pine & 33.8 & 32.4 & -- & 1.4 & -- \\
\hline Balsam fir & 626.0 & 106.1 & 362.9 & 157.0 & -- \\
\hline White spruce & 60.1 & 13.0 & 17.1 & 30.0 & -- \\
\hline Black spruce & 745.7 & 24.0 & 304.4 & 417.3 & -- \\
\hline Northern white-cedar & 317.8 & 110.2 & 153.0 & 54.6 & -- \\
\hline Tamarack & 157.6 & 9.8 & 53.6 & 94.2 & -- \\
\hline 0ak-hickory & 5.4 & -- & 5.4 & - & -- \\
\hline Elm-ash-cottonwood & 243.7 & 45.0 & 138.8 & 59.9 & -- \\
\hline Maple-basswood & 214.5 & 106.0 & 79.8 & 28.7 & -- \\
\hline Aspen & $1,947.4$ & 260.5 & $1,120.5$ & 566.4 & -- \\
\hline Paper birch & 546.3 & 69.4 & 419.2 & 57.7 & -- \\
\hline Balsam poplar & 208.0 & 49.0 & 106.2 & 52.8 & - \\
\hline Nonstocked & 65.0 & -- & -- & -- & 65.0 \\
\hline All types & $5,451.4$ & 942.9 & $2,847.1$ &, 596.4 & 65.0 \\
\hline
\end{tabular}


NORTHERN PINE

\begin{tabular}{|c|c|c|c|c|c|}
\hline \multirow{2}{*}{$\begin{array}{l}\text { Forest } \\
\text { type }\end{array}$} & \multirow[b]{2}{*}{$\begin{array}{l}\text { All } 1 \\
\text { stands }\end{array}$} & \multicolumn{4}{|c|}{ Stand-size class } \\
\hline & & $\begin{array}{l}\text { Sawtimber } \\
\text { stands }\end{array}$ & $\begin{array}{l}\text { Poletimber } \\
\text { stands }\end{array}$ & $\begin{array}{c}\text { Sapling and } \\
\text { seedling stands }\end{array}$ & $\begin{array}{l}\text { Nonstocked } \\
\text { areas }\end{array}$ \\
\hline $\begin{array}{l}\text { type } \\
\text { Jack pine }\end{array}$ & $\frac{\text { Stands }}{327.4}$ & $\begin{array}{l}\text { standas } \\
105.9\end{array}$ & $\frac{\text { stanas }}{174.6}$ & $\frac{\text { seeding stands }}{46.9}$ & $\begin{array}{r}\text { areas } \\
--\end{array}$ \\
\hline Red pine & 121.9 & 94.3 & 15.6 & 12.0 & -- \\
\hline White pine & 24.8 & 20.9 & 3.9 & -- & -- \\
\hline Balsam fir & 225.6 & 31.6 & 124.4 & 69.6 & -- \\
\hline White spruce & 19.1 & 8.7 & 6.4 & 4.0 & -- \\
\hline Black spruce & 278.2 & 7.1 & 80.8 & 190.3 & -- \\
\hline Northern white-cedar & 180.8 & 35.3 & 122.5 & 23.0 & -- \\
\hline Tamarack & 276.0 & 26.1 & 132.2 & 117.7 & -- \\
\hline Oak-hickory & 247.4 & 65.5 & 143.5 & 38.4 & $=-$ \\
\hline Elm-ash-cottonwood & 309.8 & 76.4 & 169.5 & 63.9 & -- \\
\hline Maple-basswood & 466.4 & 179.0 & 252.9 & 34.5 & -- \\
\hline Aspen & $2,541.7$ & 452.4 & $1,451.4$ & 637.9 & -- \\
\hline Paper birch & 371.2 & 55.9 & 288.3 & 27.0 & -- \\
\hline Balsam poplar & 297.5 & 66.7 & 116.5 & 114.3 & -- \\
\hline Nonstocked & 70.6 & -- & -- & -- & 70.6 \\
\hline All types & $5,758.4$ & $1,225.8$ & $3,082.5$ & $1,379.5$ & 70.6 \\
\hline \multicolumn{6}{|c|}{ CENTRAL HARDWOOD } \\
\hline Jack pine & 11.3 & 3.1 & 6.3 & 1.9 & -- \\
\hline Red pine & 10.6 & 1.6 & 6.3 & 2.7 & -- \\
\hline White pine & 7.0 & 5.1 & -- & 1.9 & -- \\
\hline Balsam fir & 7.5 & 2.3 & 3.2 & 2.0 & -- \\
\hline White spruce & $=-$ & -- & -- & -- & -- \\
\hline Black spruce & 17.9 & -- & 5.1 & 12.8 & -- \\
\hline Northern white-cedar & -- & $=-$ & -- & $=$ & $=-$ \\
\hline Tamarack & 30.8 & 7.6 & 14.5 & 8.7 & -- \\
\hline 0ak-hickory & 571.8 & 343.2 & 194.0 & 34.6 & -- \\
\hline Elm-ash-cottonwood & 129.5 & -39.1 & 62.7 & 27.7 & -- \\
\hline Maple-basswood & 485.8 & 296.7 & 147.4 & 41.7 & -- \\
\hline Aspen & 560.2 & 70.1 & 349.1 & 141.0 & -- \\
\hline Paper birch & 80.1 & 16.7 & 51.1 & 12.3 & -- \\
\hline Bal sam poplar & 10.7 & -- & 8.1 & 2.6 & -- \\
\hline Nonstocked & 27.9 & -- & -- & -- & 27.9 \\
\hline All types & $1,951.1$ & 785.5 & 847.8 & 289.9 & 27.9 \\
\hline \multicolumn{6}{|c|}{ PRAIRIE } \\
\hline Jack pine & -- & -- & -- & -- & $=-$ \\
\hline Red pine & -- & -- & -- & -- & -- \\
\hline White pine & -- & -- & -- & -- & -- \\
\hline Balsam fir & -- & -- & -- & -- & -- \\
\hline White spruce & -- & -- & -- & $=-$ & -- \\
\hline Black spruce & -- & -- & -- & -- & -- \\
\hline Northern white-cedar & -- & -- & -- & -- & -- \\
\hline Tamarack & 1.0 & -- & -- & 1.0 & -- \\
\hline Oak-hickory & 69.3 & 44.0 & 18.0 & 7.3 & -- \\
\hline Elm-ash-cottonwood & 55.1 & 34.3 & 17.8 & 3.0 & -- \\
\hline Maple-basswood & 117.2 & 93.9 & 13.4 & 9.9 & -- \\
\hline Aspen & 253.0 & 8.4 & 111.3 & 133.3 & -- \\
\hline Paper birch & -- & -- & -- & -- & -- \\
\hline Balsam poplar & 32.7 & -- & 18.2 & 14.5 & -- \\
\hline Nonstocked & 5.9 & -- & -- & $=-$ & 5.9 \\
\hline All types & 534.2 & 180.6 & 178.7 & 169.0 & 5.9 \\
\hline
\end{tabular}


Table 18.--Area of commercial forest land by county and stand-size class, Minnesota, 1977

(In thousand acres)

ASPEN-BIRCH

\begin{tabular}{|c|c|c|c|c|c|}
\hline \multirow[b]{3}{*}{ County } & \multirow{3}{*}{$\begin{array}{l}\text { All } \\
\text { stands }\end{array}$} & \multicolumn{4}{|c|}{ Stand-size class } \\
\hline & & Sawt imber & Poletimber & Sapling and & Nonstocked \\
\hline & & $\frac{\text { stands }}{38.4}$ & $\begin{array}{c}\text { stands } \\
162.2\end{array}$ & seedling stands & areas \\
\hline Carlton & 312.8 & 38.4 & 162.2 & 108.5 & 3.7 \\
\hline Cook & 538.8 & 142.5 & 295.9 & 96.4 & 4.0 \\
\hline Koochiching & $1,278.9$ & 193.7 & 589.2 & 483.2 & 12.8 \\
\hline Lake & 855.3 & 194.8 & 429.9 & 222.4 & 8.2 \\
\hline St. Louis & $2,465.6$ & 373.5 & $1,369.9$ & 685.9 & 36.3 \\
\hline All counties & $5,451.4$ & 942.9 & $2,847.1$ & $1,596.4$ & 65.0 \\
\hline \multicolumn{6}{|c|}{ NORTHERN PINE } \\
\hline Aitkin & 672.5 & 142.0 & 331.1 & 196.6 & 2.8 \\
\hline Becker & 313.9 & 81.1 & 178.9 & 53.9 & -- \\
\hline Beltrami & 794.6 & 154.8 & 428.6 & 196.3 & 14.9 \\
\hline Cass & 858.6 & 189.0 & 515.3 & 148.8 & 5.5 \\
\hline Clearwater & 301.7 & 77.5 & 150.4 & 72.1 & 1.7 \\
\hline Crow wing & 371.9 & 81.7 & $=223.4$ & 64.3 & 2.5 \\
\hline Hubbard & 398.0 & 71.5 & 242.8 & 83.7 & -- \\
\hline Itasca & $1,281.0$ & 308.5 & 677.2 & 271.7 & 23.6 \\
\hline Lake of the Woods & 360.6 & 49.6 & 144.9 & 149.3 & 16.8 \\
\hline Mahnomen & 106.4 & 22.4 & 56.5 & 27.5 & -- \\
\hline Roseau & 191.9 & 29.7 & 72.3 & 87.1 & 2.8 \\
\hline Wadena & 107.3 & 18.0 & 61.1 & 28.2 & -- \\
\hline All counties & $5,758.4$ & $1,225.8$ & $3,082.5$ & $1,379.5$ & 70.6 \\
\hline \multicolumn{6}{|c|}{ CENTRAL HARDWOOD } \\
\hline Anoka & 36.6 & 19.5 & 10.6 & 5.6 & 0.9 \\
\hline Benton & 26.1 & 13.1 & 8.3 & 4.5 & 0.2 \\
\hline Carver & 10.4 & 6.6 & 2.4 & 1.2 & 0.2 \\
\hline Chisago & 50.2 & 24.1 & 17.1 & 7.9 & 1.1 \\
\hline Jakota & 16.5 & 7.5 & 6.7 & 1.8 & 0.5 \\
\hline Jouglas & 18.5 & 6.5 & 8.0 & 3.5 & 0.5 \\
\hline Fillmore & 65.3 & 35.4 & 22.5 & 6.8 & 0.6 \\
\hline Goodhue & 56.4 & 32.2 & 18.6 & 5.1 & 0.5 \\
\hline Hennepin & 7.8 & 4.6 & 1.9 & 0.9 & 0.4 \\
\hline fouston & 111.5 & 71.7 & 29.7 & 9.7 & 0.4 \\
\hline Isanti & 46.9 & 17.8 & 18.7 & 9.2 & 1.2 \\
\hline Kanabec & 129.0 & 41.2 & 68.8 & 17.3 & 1.7 \\
\hline -e Sueur & 10.0 & 5.8 & 2.9 & 1.0 & 0.3 \\
\hline Mille Lacs & 122.8 & 39.1 & 64.6 & 17.2 & 1.9 \\
\hline Morrison & 148.7 & 68.9 & 55.9 & 21.6 & 2.3 \\
\hline Dlmsted & 32.0 & 18.0 & 10.0 & 3.7 & 0.3 \\
\hline Dtter Tail & 186.3 & 53.3 & 101.0 & 28.6 & 3.4 \\
\hline oine & 425.6 & 84.9 & 246.1 & 89.0 & 5.6 \\
\hline Ramsey & - & -- & -- & - & -- \\
\hline Rice & 12.1 & 7.2 & 3.3 & 1.3 & 0.3 \\
\hline cott & 13.6 & 8.6 & 3.2 & 1.4 & 0.4 \\
\hline Sherburne & 56.9 & 31.2 & 17.0 & 8.4 & 0.3 \\
\hline tearns & 56.0 & 33.6 & 15.5 & 6.6 & 0.3 \\
\hline Todd & 104.5 & 37.7 & 47.1 & 17.1 & 2.6 \\
\hline Nabasha & 57.4 & 30.7 & 19.9 & 6.0 & 0.8 \\
\hline Vashington & 10.2 & 5.6 & 3.2 & 1.2 & 0.2 \\
\hline Vinona & 106.3 & 66.0 & 30.8 & 9.1 & 0.4 \\
\hline Vright & 33.5 & 14.7 & 14.0 & 4.2 & 0.6 \\
\hline All counties & $1,951.1$ & 785.5 & 847.8 & 289.9 & 27.9 \\
\hline
\end{tabular}


(Table 18 continued)

PRAIRIE

\begin{tabular}{|c|c|c|c|c|c|c|}
\hline & All & Sawt imber & Poletimber & $\frac{2 e \text { class }}{\text { Sapling and }}$ & Nonstocked & \\
\hline County & stands & stands & stands & seedling stands & areas & \\
\hline Big Stone & 2.4 & 1.0 & 0.7 & 0.7 & - & \\
\hline Blue Earth & 21.4 & 15.3 & 3.3 & 2.5 & 0.3 & \\
\hline Brown & 9.1 & 6.5 & 1.5 & 1.0 & 0.1 & \\
\hline Chippewa & 3.9 & 1.3 & 1.3 & 1.2 & 0.1 & \\
\hline Clay & 10.3 & 3.7 & 3.2 & 3.3 & 0.1 & \\
\hline Cottonwood & 2.5 & 1.2 & 0.9 & 0.4 & - & \\
\hline Dodge & 6.4 & 5.0 & 0.9 & 0.4 & 0.1 & \\
\hline Fajrbault & 6.2 & 4.0 & 1.3 & 0.9 & - & \\
\hline Freeborn & 4.8 & 3.3 & 0.8 & 0.6 & 0.1 & \\
\hline Grant & 2.9 & 1.4 & 1.1 & 0.4 & - & \\
\hline Jackson & 2.1 & 1.4 & 0.5 & 0.2 & -- & \\
\hline Kandiyohi & 9.9 & 6.0 & 2.1 & 1.7 & 0.1 & \\
\hline Kittson & 67.5 & 6.3 & 28.0 & 32.5 & 0.7 & \\
\hline Lac qui Parle & 4.6 & 2.3 & 1.2 & 1.1 & -- & \\
\hline Lincoln & 2.0 & 1.4 & 0.5 & 0.1 & -- & \\
\hline Lyon & 4.4 & 2.3 & 1.1 & 0.9 & 0.1 & \\
\hline McLeod & 5.8 & 4.3 & 1.0 & 0.5 & - & \\
\hline Marshall & 128.5 & 16.7 & 47.7 & 62.9 & 1.2 & \\
\hline Martin & 3.6 & 2.0 & 1.1 & 0.4 & 0.1 & \\
\hline Meeker & 10.8 & 8.8 & 0.7 & 1.0 & 0.3 & \\
\hline Mower & 5.2 & 4.0 & 0.8 & 0.3 & 0.1 & \\
\hline Murray & 1.1 & 0.6 & 0.3 & 0.2 & -- & \\
\hline Nicollet & 12.3 & 9.3 & 1.4 & 1.3 & 0.3 & \\
\hline Nobles & 0.7 & 0.3 & 0.3 & 0.1 & -- & \\
\hline Norman & 22.2 & 6.4 & 9.6 & 5.9 & 0.3 & \\
\hline Pennington & 30.7 & 6.3 & 14.3 & 9.9 & 0.2 & \\
\hline Pipestone & 0.4 & 0.2 & 0.2 & -- & - & \\
\hline Polk & 68.0 & 20.7 & 26.1 & 20.5 & 0.7 & \\
\hline Pope & 6.9 & 2.4 & 2.4 & 2.0 & 0.1 & \\
\hline Red Lake & 27.2 & 5.3 & 13.0 & 8.7 & 0.2 & \\
\hline Redwood & 6.2 & 3.1 & 1.8 & 1.2 & 0.1 & \\
\hline Renville & 7.2 & 4.5 & 1.5 & 1.1 & 0.1 & \\
\hline Rock & 0.5 & 0.2 & 0.2 & 0.1 & -- & \\
\hline Sibley & 10.9 & 8.0 & 1.8 & 1.0 & 0.1 & \\
\hline Steele & 5.0 & 3.6 & 0.8 & 0.5 & 0.1 & \\
\hline Stevens & 1.0 & 0.4 & 0.4 & 0.2 & -- & \\
\hline Swift & 4.7 & 2.0 & 1.6 & 1.0 & 0.1 & \\
\hline Traverse & 0.9 & 0.3 & 0.3 & 0.3 & $-\infty$ & \\
\hline Waseca & 4.6 & 3.5 & 0.5 & 0.5 & 0.1 & \\
\hline Watonwan & 1.1 & 0.6 & 0.2 & 0.3 & - & \\
\hline Wilkin & 0.5 & 0.1 & 0.1 & 0.3 & $=-$ & \\
\hline Yellow Medicine & 7.8 & 4.6 & 2.2 & 0.9 & 0.1 & \\
\hline All counties & 534.2 & 180.6 & 178.7 & 169.0 & 5.9 & \\
\hline All units & $13,695.1$ & $3,134.8$ & $6,956.1$ & $3,434.8$ & 169.4 & \\
\hline
\end{tabular}


Table 19.--Area of commercial forest land by forest type, stand-size class, and site class, Minnesota, 1977

(In thousand acres)

\begin{tabular}{|c|c|c|c|c|c|c|c|}
\hline \multirow[b]{2}{*}{$\begin{array}{l}\text { Forest type and } \\
\text { stand-size class }\end{array}$} & \multirow[b]{2}{*}{$\begin{array}{c}\text { Al1 } \\
\text { classes } \\
\end{array}$} & \multicolumn{6}{|c|}{ Site class (cubic feet of growth/acre/year) } \\
\hline & & $\begin{array}{c}225 \\
\text { or more }\end{array}$ & $\begin{array}{l}165- \\
224 \\
\end{array}$ & $\begin{array}{l}120- \\
164 \\
\end{array}$ & $\begin{array}{l}85- \\
119 \\
\end{array}$ & $\begin{array}{l}50- \\
84 \\
\end{array}$ & $\begin{array}{l}20- \\
49\end{array}$ \\
\hline \multicolumn{8}{|l|}{ Jack pine } \\
\hline Sawtimber & 177.3 & -- & -- & 1.4 & 3.8 & 77.3 & 94.8 \\
\hline Poletimber & 247.2 & -- & -- & -- & 10.4 & 100.8 & 136.0 \\
\hline Sapling \& seedling & 79.9 & -- & -- & -- & -- & 40.4 & 39.5 \\
\hline All stands & 504.4 & -- & -- & 1.4 & 14.2 & 218.5 & 270.3 \\
\hline \multicolumn{8}{|l|}{ Red pine } \\
\hline Sawtimber & 145.1 & -- & -- & 1.4 & 46.7 & 72.5 & 24.5 \\
\hline Poletimber & 41.8 & -- & -- & 4.0 & 13.7 & 10.3 & 13.8 \\
\hline Sapling \& seedling & 60.0 & -- & -- & -- & 6.9 & 30.8 & 22.3 \\
\hline All stands & 246.9 & -- & -- & 5.4 & 67.3 & 113.6 & 60.6 \\
\hline \multicolumn{8}{|l|}{ White pine } \\
\hline Sawtimber & 58.4 & -- & 2.8 & 8.6 & 21.8 & 12.3 & 12.9 \\
\hline Poletimber & 3.9 & -- & -- & -- & 3.9 & -- & - \\
\hline Sapling \& seedling & 3.3 & -- & -- & -- & 3.3 & - & -- \\
\hline All stands & 65.6 & -- & 2.8 & 8.6 & 29.0 & 12.3 & 12.9 \\
\hline \multicolumn{8}{|l|}{ Ba)sam fir } \\
\hline Sawtimber & 140.0 & -- & 2.7 & 24.5 & 57.7 & 27.3 & 27.8 \\
\hline Poletimber & 490.5 & -- & 1.2 & 37.7 & 174.4 & 125.3 & 151.9 \\
\hline Sapl ing \& seedling & 228.6 & -- & -- & 16.3 & 54.0 & 61.3 & 97.0 \\
\hline All stands & 859.1 & -- & 3.9 & 78.5 & 286.1 & 213.9 & 276.7 \\
\hline \multicolumn{8}{|l|}{ White spruce } \\
\hline Sawtimber & 21.7 & -- & -- & -- & 3.9 & 12.6 & 5.2 \\
\hline Poletimber & 23.5 & -- & - & -- & 1.7 & 16.7 & 5.1 \\
\hline Sapl ing \& seedling & 34.0 & -- & -- & -- & 5.9 & 15.5 & 12.6 \\
\hline All stands & 79.2 & -- & -- & -- & 11.5 & 44.8 & 22.9 \\
\hline \multicolumn{8}{|l|}{ BTack spruce } \\
\hline Sawtimber & 31.1 & -- & -- & -- & -- & 2.6 & 28.5 \\
\hline Poletimber & 390.3 & -- & -- & -- & 6.9 & 20.2 & 363.2 \\
\hline Sapling \& seedling & 620.4 & -- & -- & -- & 1.3 & 14.8 & 604.3 \\
\hline A1 1 stands & $1,041.8$ & -- & -- & -- & 8.2 & 37.6 & 996.0 \\
\hline \multicolumn{8}{|l|}{ Northern white-cedar } \\
\hline Sawtimber & 145.5 & -- & -- & -- & -- & 2.8 & 142.7 \\
\hline Poletimber & 275.5 & -- & -- & -- & -- & 17.1 & 258.4 \\
\hline Sapling \& seedling & 77.6 & -- & - & -- & -- & -- & 77.6 \\
\hline All stands & 498.6 & -- & -- & -- & -- & 19.9 & 478.7 \\
\hline
\end{tabular}


(Table 19 continued)

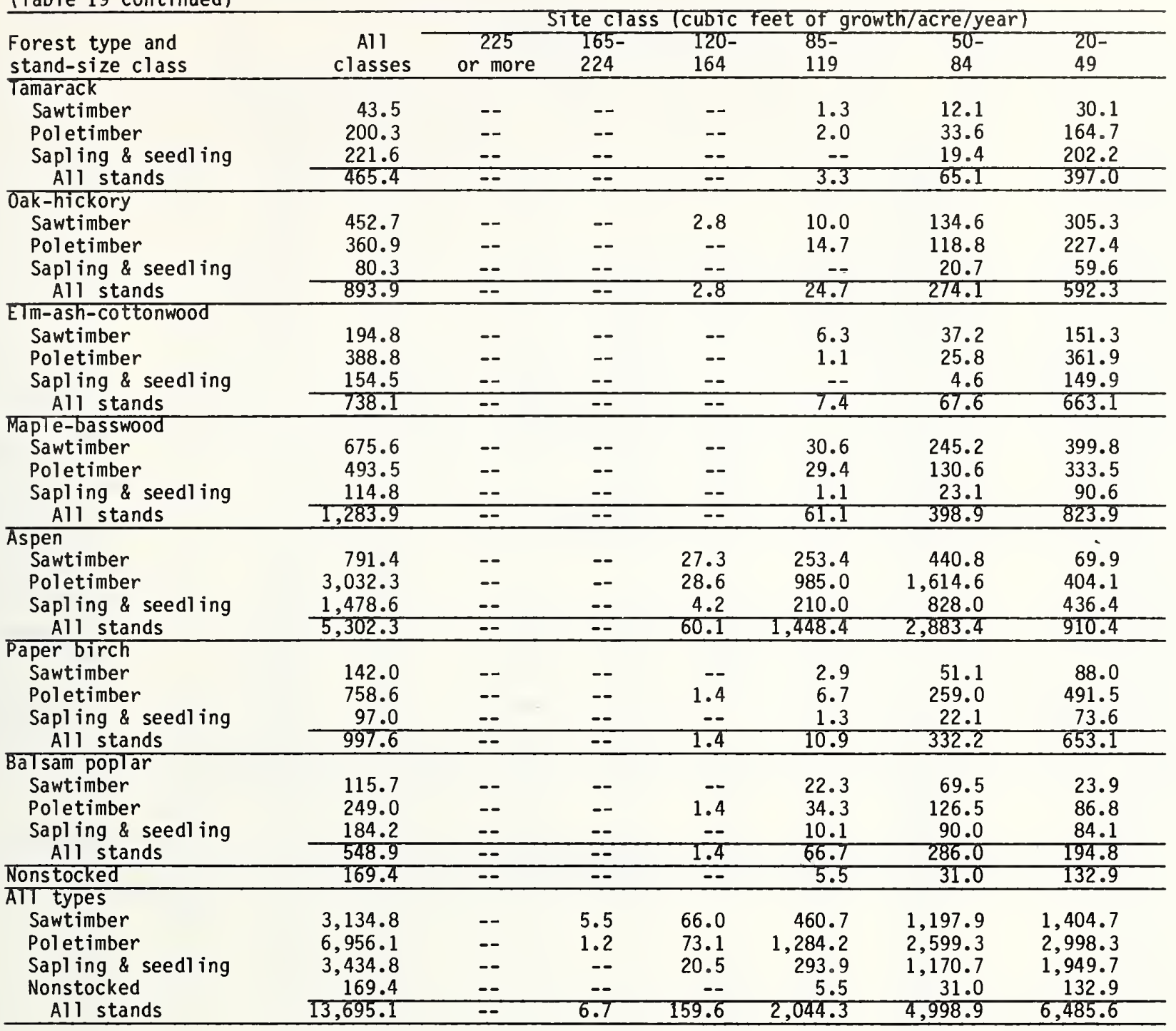


Table 20.--Area of commercial forest land by forest type, site-index class, and

Forest Survey Unit, Minnesota, 1977

(In thousand acres)

ALL UNITS

\begin{tabular}{|c|c|c|c|c|c|c|c|c|c|c|}
\hline \multirow{2}{*}{$\begin{array}{l}\text { Forest } \\
\text { type }\end{array}$} & \multirow{2}{*}{$\begin{array}{c}\text { All } \\
\text { classes }\end{array}$} & \multicolumn{9}{|c|}{ Site-index class (feet) } \\
\hline & & $11-20$ & $21-30$ & $31-40$ & $41-50$ & $51-60$ & $61-70$ & $71-80$ & $81-90$ & $91+$ \\
\hline Jack pine & 504.4 & -0 & -0 & 18.2 & 112.4 & 194.3 & 132.7 & 40.0 & 5.4 & 1.4 \\
\hline Red pine & 246.9 & -- & -- & 5.8 & 36.4 & 118.2 & 42.7 & 43.8 & -- & -- \\
\hline White pine & 65.6 & -- & -- & 3.7 & 18.8 & 29.5 & 10.7 & 2.9 & -- & -- \\
\hline Balsam fir & 859.1 & -- & 18.6 & 179.3 & 316.6 & 250.4 & 71.2 & 19.1 & 3.9 & -- \\
\hline White spruce & 79.2 & -- & -- & 5.8 & 32.7 & 23.8 & 16.9 & -- & -- & -- \\
\hline Black spruce & $1,041.8$ & 27.2 & 369.8 & 375.1 & 223.9 & 37.6 & 6.9 & 1.3 & -- & -- \\
\hline Northern white-cedar & 498.6 & 85.8 & 278.0 & 95.2 & 25.7 & 10.0 & 3.9 & -- & -- & -- \\
\hline Tamarack & 465.4 & 4.5 & 91.6 & 168.1 & 132.8 & 52.3 & 12.8 & 3.3 & -- & -- \\
\hline 0ak-hickory & 893.9 & - & 7.5 & 164.3 & 307.2 & 225.7 & 134.9 & 39.5 & 12.0 & 2.8 \\
\hline Elm-ash-cottonwood & 738.1 & -- & 3.2 & 136.3 & 218.8 & 259.3 & 82.5 & 30.6 & 5.9 & 1.5 \\
\hline Maple-basswood & $1,283.9$ & -- & -- & 63.4 & 303.0 & 465.1 & 316.5 & 103.8 & 32.1 & - \\
\hline As pen & $5,302.3$ & 1.4 & 12.3 & 73.1 & 397.7 & $1,225.1$ & $1,780.0$ & $1,286.2$ & 466.4 & 60.1 \\
\hline Paper birch & 997.6 & -- & 3.0 & 47.0 & 186.7 & 388.9 & 290.1 & 69.5 & 11.0 & 1.4 \\
\hline Balsam poplar & 548.9 & -- & -- & 25.4 & 111.2 & 134.1 & 169.9 & 73.7 & 30.4 & 4.2 \\
\hline Nonstocked & 169.4 & 4.3 & 20.8 & 31.1 & 51.1 & 36.1 & 20.6 & 5.4 & -- & -- \\
\hline All types & $13,695.1$ & 123.2 & 804.8 & 391.8 & $2,475.0$ & $3,450.4$ & $3,092.3$ & $1,719.1$ & 567.1 & 71.4 \\
\hline \multicolumn{11}{|c|}{ ASPEN-BIRCH } \\
\hline Jack pine & 165.7 & -- & -- & 5.4 & 55.9 & 78.5 & 20.7 & 5.2 & $=$ & -- \\
\hline Red pine & 114.4 & -- & -- & 1.3 & 22.1 & 66.1 & 21.0 & 3.9 & -- & -- \\
\hline White pine & 33.8 & -- & -- & 3.7 & 15.0 & 11.6 & 3.5 & -. & -- & -- \\
\hline Balsam fir & 626.0 & -- & 11.0 & 106.0 & 245.6 & 195.0 & 56.2 & 9.5 & 2.7 & -- \\
\hline White spruce & 60.1 & -- & -- & 5.8 & 21.7 & 21.0 & 11.6 & -- & -- & -- \\
\hline Black spruce & 745.7 & 21.6 & 248.3 & 270.1 & 169.9 & 29.2 & 5.3 & 1.3 & -- & -- \\
\hline Northern white-cedar & 317.8 & 52.0 & 182.9 & 54.4 & 17.9 & 6.7 & 3.9 & - & - & -- \\
\hline Tamarack & 157.6 & 1.2 & 40.8 & 51.5 & 44.4 & 17.0 & 2.7 & -- & - & -- \\
\hline 0ak-hickory & 5.4 & - & -- & -- & 1.2 & 1.4 & 1.4 & 1.4 & -- & -- \\
\hline Elm-ash-cottonwood & 243.7 & -- & -- & 57.6 & 97.2 & 75.4 & 10.5 & 3.0 & -- & -- \\
\hline Maple-basswood & 214.5 & -- & -- & 14.2 & 75.0 & 82.6 & 39.0 & 2.7 & 1.0 & -- \\
\hline Aspen & $1,947.4$ & -- & 8.9 & 20.3 & 156.0 & 530.7 & 698.2 & 391.8 & 118.9 & 22.6 \\
\hline Paper birch & 546.3 & -- & 1.4 & 36.7 & 112.0 & 223.5 & 144.0 & 27.2 & 1.5 & -- \\
\hline Balsam poplar & 208.0 & -- & -- & 8.6 & 28.8 & 52.2 & 64.2 & 33.4 & 18.0 & 2.8 \\
\hline Nonst ocked & 65.0 & -- & 3.5 & 9.3 & 33.7 & 7.2 & 8.4 & 2.9 & - & -- \\
\hline All types & $5,451.4$ & 74.8 & 496.8 & 644.9 & $1,096.4$ & $1,398.1$ & $1,090.6$ & 482.3 & 142.1 & 25.4 \\
\hline \multicolumn{11}{|c|}{ NORTHERN PINE } \\
\hline Jack pine & 327.4 & $=-$ & -- & 12.8 & 54.6 & 112.7 & 109.8 & 30.7 & 5.4 & 1.4 \\
\hline Red pine & 121.9 & -- & -- & 4.5 & 14.3 & 47.4 & 17.7 & 38.0 & -- & -- \\
\hline White pine & 24.8 & - & -- & - & 2.5 & 15.3 & 5.6 & 1.4 & -- & -- \\
\hline Balsam fir & 225.6 & -- & 7.6 & 71.3 & 69.6 & 51.3 & 15.0 & 9.6 & 1.2 & -- \\
\hline White spruce & 19.1 & -- & - & -- & 11.0 & 2.8 & 5.3 & -- & -- & -- \\
\hline Black spruce & 278.2 & 5.6 & 120.0 & 91.5 & 51.1 & 8.4 & 1.6 & -- & -- & - \\
\hline Northern white-cedar & 180.8 & 33.8 & 95.1 & 40.8 & 7.8 & 3.3 & -- & -- & -- & -- \\
\hline Tamarack & 276.0 & 3.3 & 49.1 & 113.2 & 71.1 & 30.7 & 7.3 & 1.3 & -- & -- \\
\hline 0ak-hickory & 247.4 & - & 4.6 & 34.9 & 92.8 & 67.0 & 34.5 & 9.4 & 4.2 & -- \\
\hline Elm-ash-cottonwood & 309.8 & -- & 1.4 & 56.3 & 82.6 & 119.1 & 39.2 & 10.1 & 1.1 & -- \\
\hline Maple-basswood & 466.4 & -- & -- & 21.7 & 100.1 & 171.9 & 116.8 & 39.9 & 16.0 & -- \\
\hline Aspen & $2,541.7$ & 1.4 & 1.8 & 36.9 & 139.9 & 440.0 & 808.1 & 743.0 & 333.1 & 37.5 \\
\hline Paper birch & 371.2 & - & - & 4.9 & 54.8 & 143.1 & 122.0 & 35.5 & 9.5 & 1.4 \\
\hline Balsam poplar & 297.5 & -- & -- & 12.3 & 65.5 & 68.6 & 98.5 & 38.8 & 12.4 & 1.4 \\
\hline Nonstocked & 70.6 & 4.3 & 15.8 & 11.8 & 10.3 & 18.1 & 7.8 & 2.5 & -- & - \\
\hline All types & $5,758.4$ & 48.4 & 295.4 & 512.9 & 828.0 & $1,299.7$ & $1,389.2$ & 960.2 & 382.9 & 41.7 \\
\hline
\end{tabular}


(Table 20 continued)

CENTRAL HARDWOODS

\begin{tabular}{|c|c|c|c|c|c|c|c|c|c|c|}
\hline $\begin{array}{l}\text { Forest } \\
\text { type }\end{array}$ & $\begin{array}{c}\text { All } \\
\text { classes }\end{array}$ & $11-20$ & $21-30$ & $31-40$ & $\frac{\text { site }}{41-50}$ & $\frac{d e x c T}{51-60}$ & $\frac{(\text { feet })}{61-70}$ & $71-80$ & $81-90$ & $91+$ \\
\hline Jack pine & 11.3 & $=-$ & $\frac{-0}{-1-20}$ & $\frac{-10}{-0}$ & $\frac{71-70}{1.9}$ & 3.1 & 2.2 & 4.1 & -- & 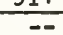 \\
\hline Red pine & 10.6 & -- & -- & -- & -- & 4.7 & 4.0 & 1.9 & -- & -- \\
\hline White pine & 7.0 & -- & -- & -- & 1.3 & 2.6 & 1.6 & 1.5 & -- & -- \\
\hline Balsam fir & 7.5 & -- & - & 2.0 & 1.4 & 4.1 & -- & -- & -- & -- \\
\hline White spruce & -- & -- & - & -- & -- & - & -- & -- & - & -- \\
\hline Black spruce & 17.9 & - & 1.5 & 13.5 & 2.9 & -- & -- & -- & -- & -- \\
\hline Northern white-cedar & -- & -- & -- & -- & -- & -- & -- & -- & -- & -- \\
\hline Tamarack & 30.8 & -- & 0.7 & 3.4 & 17.3 & 4.6 & 2.8 & 2.0 & -- & -- \\
\hline 0ak-hickory & 571.8 & -- & 1.6 & 98.2 & 195.2 & 144.6 & 92.9 & 28.7 & 7.8 & 2.8 \\
\hline Elm-ash-cottonwood & 129.5 & -- & 1.8 & 13.5 & 27.3 & 45.8 & 21.3 & 15.0 & 4.8 & -- \\
\hline Maple-basswood & 485.8 & -- & -- & 20.5 & 105.3 & 167.6 & 135.0 & 43.8 & 13.6 & -- \\
\hline Aspen & 560.2 & -- & 1.6 & 2.5 & 36.2 & 153.1 & 223.6 & 128.8 & 14.4 & -- \\
\hline Paper birch & 80.1 & -- & 1.6 & 5.4 & 19.9 & 22.3 & 24.1 & 6.8 & -- & - \\
\hline Balsam poplar & 10.7 & $=-$ & $=-$ & 1.5 & 2.9 & 3.2 & 1.6 & 1.5 & -- & -- \\
\hline Nonstocked & 27.9 & - & 1.5 & 10.0 & 2.6 & 9.4 & 4.4 & -- & -- & -- \\
\hline A1] types & $1,951.1$ & -- & 10.3 & 170.5 & 414.2 & 565.1 & 513.5 & 234.1 & 40.6 & 2.8 \\
\hline \multicolumn{11}{|c|}{ PRAIRIE } \\
\hline Jack pine & -- & -- & $=$ & -- & -- & - & -- & -- & - & -- \\
\hline Red pine & -- & -- & -- & -- & -- & -- & -- & -- & -- & -- \\
\hline White pine & -- & - & - & -- & -- & - & $=-$ & -- & -- & -- \\
\hline Balsam fir & -- & -- & $=-$ & -- & -- & - & -- & -- & -- & -- \\
\hline White spruce & -- & -- & -- & -- & - & -- & $=-$ & -- & -- & -- \\
\hline Black spruce & -- & -- & -- & -- & $=-$ & -- & -- & -- & -- & -- \\
\hline Northern white-cedar & -- & -- & -- & -- & -- & - & $=-$ & - & -- & -- \\
\hline Tamarack & 1.0 & $\cdots$ & 1.0 & -- & -- & $r^{-}$ & -- & -- & - & -- \\
\hline 0ak-hickory & 69.3 & -- & 1.3 & 31.2 & 18.0 & 12.7 & 6.1 & -- & $=-$ & -- \\
\hline Elm-ash-cottonwood & 55.1 & -- & -- & 8.9 & 11.7 & 19.0 & 11.5 & 2.5 & -- & 1.5 \\
\hline Maple-basswood & 117.2 & -- & -- & 7.0 & 22.6 & 43.0 & 25.7 & 17.4 & 1.5 & -- \\
\hline Aspen & 253.0 & -- & -- & 13.4 & 65.6 & 101.3 & 50.1 & 22.6 & -- & -- \\
\hline Paper birch & -- & - & $=-$ & -- & $=$ & -- & -- & -- & - & -- \\
\hline Balsam poplar & 32.7 & -- & -- & 3.0 & 14.0 & 10.1 & 5.6 & -- & -- & -- \\
\hline Nonstocked & 5.9 & -- & -- & -- & 4.5 & 1.4 & $-\infty$ & -- & -- & - \\
\hline All types & 534.2 & -- & 2.3 & 63.5 & 136.4 & 187.5 & 99.0 & 42.5 & 1.5 & 1.5 \\
\hline
\end{tabular}


Table 21.--Area of commercial forest land by forest type and distance to water, Minnesota, 1977

(In thousand acres)

\begin{tabular}{|c|c|c|c|c|c|c|c|c|c|}
\hline \multirow{2}{*}{ Forest type } & \multirow[b]{2}{*}{ Total } & \multicolumn{8}{|c|}{ Distance to water (miles) } \\
\hline & & $0-1 / 8$ & $1 / 8-1 / 4$ & $1 / 4-1$ & $1-2 \quad 1 / 2$ & $21 / 2-5$ & $5-10$ & $10-20$ & $20+$ \\
\hline Jack pine & 504.4 & 28.9 & 33.6 & 244.0 & 130.3 & 32.3 & 27.4 & 7.9 & -- \\
\hline Red pine & 246.9 & 5.6 & 51.6 & 64.6 & 77.1 & 44.0 & 4.0 & - & -- \\
\hline White pine & 65.6 & 5.2 & 11.4 & 28.1 & 9.8 & 11.1 & -- & -- & -- \\
\hline Balsam fir & 859.1 & 38.1 & 56.7 & 333.1 & 237.0 & 101.6 & 69.0 & 17.9 & 5.7 \\
\hline White spruce & 79.2 & 5.0 & 2.8 & 14.6 & 24.0 & 23.7 & 6.3 & -- & 2.8 \\
\hline Black spruce & $1,041.8$ & 34.7 & 52.3 & 245.6 & 305.1 & 223.2 & 146.6 & 31.3 & 3.0 \\
\hline Northern white-cedar & 498.6 & 22.4 & 18.6 & 124.6 & 99.1 & 94.8 & 112.8 & 18.4 & 7.9 \\
\hline Tamarack & 465.4 & 10.2 & 29.6 & 111.7 & 119.0 & 88.9 & 75.9 & 22.8 & 7.3 \\
\hline Oak & 893.9 & 67.6 & 79.4 & 276.6 & 208.2 & 151.0 & 109.6 & 1.5 & -- \\
\hline Elm-ash-cotwood & 738.1 & 84.7 & 42.4 & 204.1 & 184.1 & 145.2 & 68.8 & 7.5 & 1.3 \\
\hline Maple-basswood & $1,283.9$ & 168.7 & 113.7 & 375.4 & 301.4 & 237.6 & 78.0 & 7.6 & 1.5 \\
\hline Aspen & $5,302.3$ & 357.2 & 408.4 & $1,729.7$ & $1,404.4$ & 820.2 & 399.0 & 116.2 & 67.2 \\
\hline Paper birch & 997.6 & 128.5 & 96.4 & 352.4 & 248.9 & 143.2 & 15.5 & 12.7 & - \\
\hline Bal sam poplar & 548.9 & 21.2 & 22.8 & 115.3 & 124.1 & 133.9 & 82.3 & 32.0 & 17.3 \\
\hline Nonstocked & 169.4 & 13.4 & 5.6 & 50.3 & 46.4 & 26.6 & 19.8 & -- & 7.3 \\
\hline Total & $13,695.1$ & 991.4 & $1,025.3$ & $4,270.1$ & $3,518.9$ & $2,277.3$ & $1,215.0$ & 275.8 & 121.3 \\
\hline
\end{tabular}

Table 22.--Area of commercial forest land by forest type and distance to road Minnesota, 1977

(In thousand acres)

\begin{tabular}{|c|c|c|c|c|c|c|c|c|c|}
\hline \multirow[b]{2}{*}{ Forest type } & \multirow[b]{2}{*}{ Total } & \multicolumn{8}{|c|}{ Distance to road (miles) } \\
\hline & & $0-1 / 8$ & $1 / 8-1 / 4$ & $1 / 4-1$ & $1-21 / 2$ & $21 / 2-5$ & $5-10$ & $10-20$ & $20+$ \\
\hline Jack pine & 504.4 & 228.1 & 65.6 & 159.4 & 46.0 & 3.9 & -- & -- & 1.4 \\
\hline Red pine & 246.9 & 130.4 & 51.3 & 51.8 & 12.2 & -- & 1.2 & -- & -- \\
\hline White pine & 65.6 & 31.3 & 4.0 & 24.5 & 4.4 & -- & 1.4 & -- & -- \\
\hline Balsam fir & 859.1 & 238.9 & 93.7 & 330.4 & 153.5 & 34.1 & 8.5 & -- & -- \\
\hline White spruce & 79.2 & 38.6 & 10.7 & 15.4 & 13.1 & 1.4 & -- & -- & -- \\
\hline Black spruce & $1,041.8$ & 206.3 & 73.3 & 347.7 & 282.7 & 92.5 & 29.8 & 1.3 & 8.2 \\
\hline Northern white-cedar & 498.6 & 83.2 & 37.0 & 189.3 & 107.4 & 51.3 & 20.6 & 9.8 & -- \\
\hline Tamarack & 465.4 & 38.8 & 69.1 & 186.0 & 89.5 & 54.1 & 16.7 & 2.9 & 8.3 \\
\hline Oak & 893.9 & 206.0 & 190.9 & 463.0 & 32.7 & 1.3 & -- & -- & -- \\
\hline Elm-ash-cottonwood & 738.1 & 151.2 & 103.6 & 355.9 & 97.6 & 16.2 & 9.6 & -- & 4.0 \\
\hline Maple-basswood & $1,283.9$ & 352.2 & 241.4 & 536.8 & 122.4 & 18.9 & 5.1 & -- & 7.1 \\
\hline Aspen & $5,302.3$ & $1,443.1$ & 835.0 & $2,204.4$ & 668.7 & 125.1 & 17.8 & 4.0 & 4.2 \\
\hline Paper birch & 997.6 & 315.8 & 132.3 & 383.7 & 130.6 & 28.1 & 2.7 & 1.7 & 2.7 \\
\hline Balsam poplar & 548.9 & 98.0 & 117.3 & 251.1 & 65.2 & 12.9 & 1.7 & 1.3 & 1.4 \\
\hline Nonstocked & 169.4 & 47.0 & 22.3 & 54.9 & 25.8 & 12.5 & 3.0 & -- & 3.9 \\
\hline Tota 1 & $13,695.1$ & $3,608.9$ & $2,047.5$ & $5,554.3$ & $1,851.8$ & 452.3 & 118.1 & 21.0 & 41.2 \\
\hline
\end{tabular}


Table 23.--Area of commercial forest land by forest type and stand area class, Minnesota, 1977

(In thousand acres)

\begin{tabular}{|c|c|c|c|c|c|c|c|c|c|c|}
\hline \multirow[b]{2}{*}{ Forest type } & \multirow[b]{2}{*}{ Total } & \multicolumn{9}{|c|}{ Stand area class } \\
\hline & & $1-4$ & $4-9$ & $10-19$ & $20-39$ & $40-79$ & $\begin{array}{r}80- \\
159 \\
\end{array}$ & $\begin{array}{l}160- \\
319\end{array}$ & $\begin{array}{l}320- \\
639 \\
\end{array}$ & $640+$ \\
\hline Jack pine & 504.4 & 149.6 & 95.3 & 91.5 & 72.0 & 44.7 & 23.1 & 9.1 & -- & 19.1 \\
\hline Red pine & 246.9 & 85.0 & 36.8 & 21.4 & 53.7 & 8.7 & 10.9 & 1.7 & -- & 28.7 \\
\hline White pine & 65.6 & 16.5 & 29.4 & 2.8 & 11.1 & 1.4 & -- & -- & 4.4 & -- \\
\hline Balsam fir & 859.1 & 357.7 & 247.3 & 131.5 & 63.2 & 3.2 & 12.9 & 4.1 & 38.0 & 1.2 \\
\hline White spruce & 79.2 & 33.7 & 21.7 & 16.9 & 1.3 & 1.4 & 1.9 & -- & -- & 2.3 \\
\hline Black spruce & $1,041.8$ & 334.6 & 232.8 & 196.7 & 127.8 & 50.6 & 67.4 & 11.4 & 2.9 & 17.6 \\
\hline Northern white-cedar & 498.6 & 146.9 & 175.0 & 87.6 & 53.3 & 13.3 & 10.4 & 3.5 & 4.6 & 4.0 \\
\hline Tamarack & 465.4 & 135.0 & 102.0 & 89.3 & 65.6 & 36.2 & 29.7 & 2.5 & 1.3 & 3.8 \\
\hline Oak & 893.9 & 105.2 & 90.6 & 132.1 & 129.5 & 125.2 & 240.9 & 50.7 & 16.1 & 3.6 \\
\hline Elm-ash-cottonwood & 738.1 & 205.3 & 201.7 & 123.9 & 76.5 & 42.7 & 40.6 & 9.6 & 3.1 & 34.7 \\
\hline Maple-basswood & $1,283.9$ & 182.8 & 226.5 & 262.6 & 218.1 & 135.8 & 156.7 & 39.8 & 18.5 & 43.1 \\
\hline Aspen & $5,302.3$ & $1,299.2$ & $1,023.5$ & 1.008 .9 & 792.6 & 440.9 & 483.4 & 116.6 & 40.2 & 97.0 \\
\hline Paper birch & 997.6 & 187.0 & 203.4 & 228.0 & 167.1 & 85.6 & 65.6 & 25.6 & 15.2 & 20.1 \\
\hline Balsam poplar & 548.9 & 219.6 & 125.7 & 92.2 & 65.9 & 27.2 & 12.6 & 4.2 & 1.5 & -- \\
\hline Nonstocked & 169.4 & 61.0 & 51.3 & 19.3 & 16.9 & 1.6 & 4.4 & $1 . \overline{7}$ & 6.6 & 6.6 \\
\hline Total & $13,695.1$ & $3,519.1$ & $2,863.0$ & $2,504.7$ & $1,914.6$ & $1,018.5$ & $1,160.5$ & 280.5 & 152.4 & 281.8 \\
\hline
\end{tabular}


Table 24.--Area of noncommercial forest land by ownership class and Forest Survey Unit, Minnesota, 1977

(In thousand acres)

ALL UNITS

\begin{tabular}{|c|c|c|c|}
\hline Ownership class & $\begin{array}{l}\text { AाT } \\
\text { areas }\end{array}$ & $\begin{array}{l}\text { Productive- } \\
\text { reserved areas }\end{array}$ & $\begin{array}{c}\text { Unproductive } \\
\text { areas }\end{array}$ \\
\hline National forest & 884.3 & 758.7 & 125.6 \\
\hline other federal & 253.8 & 126.7 & 127.1 \\
\hline State, county & & & \\
\hline and municipal & $1,560.3$ & 281.6 & $1,278.7$ \\
\hline Forest industry & 35.2 & - & 35.2 \\
\hline Farmer & 211.1 & -- & 211.1 \\
\hline Miscellaneous & 69.4 & 11,6 & 57.8 \\
\hline All owners & $\frac{69.4}{3,014.1}$ & $\begin{array}{r}11.6 \\
1,178.6\end{array}$ & $1,835.5$ \\
\hline \multicolumn{4}{|c|}{ ASPEN-BIRCH } \\
\hline National forest & 856.1 & 756.8 & 99.3 \\
\hline 0ther federal & 175.6 & 121.6 & 54.0 \\
\hline \multicolumn{4}{|l|}{ State, county } \\
\hline and municipal & 872.8 & 165.7 & 707.1 \\
\hline Forest industry & 30.9 & -- & 30.9 \\
\hline Farmer & 55.3 & -- & 55.3 \\
\hline \multicolumn{4}{|l|}{ Miscellaneous } \\
\hline private & 29.7 & 6.5 & 23.2 \\
\hline All owners & $2,020.4$ & $1,050.6$ & 969.8 \\
\hline \multicolumn{4}{|c|}{ NORTHERN PINE } \\
\hline National forest & 28.2 & 1.9 & 26.3 \\
\hline Other federal & 70.8 & 1.7 & 69.1 \\
\hline \multicolumn{4}{|l|}{ State, county } \\
\hline and municipal & 584.4 & 43.3 & 541.1 \\
\hline Forest industry & 4.3 & -- & 4.3 \\
\hline Farmer & 53.8 & -- & 53.8 \\
\hline \multicolumn{4}{|l|}{ Miscellaneous } \\
\hline private & 12.3 & -- & 12.3 \\
\hline Al1 owners & 753.8 & 46.9 & 706.9 \\
\hline \multicolumn{4}{|c|}{ CENTRAL HARDWOODS } \\
\hline National forest & -- & -- & -- \\
\hline other federal & 3.0 & 0.1 & 2.9 \\
\hline \multicolumn{4}{|l|}{ State, county } \\
\hline and municipal & 90.0 & 67.2 & 22.8 \\
\hline Forest industry & -- & -- & -- \\
\hline Farmer & 78.8 & -- & 78.8 \\
\hline \multicolumn{4}{|l|}{ Miscell aneous } \\
\hline private & 20.8 & 5.1 & 15.7 \\
\hline Al1 owners & 192.6 & 72.4 & 120.2 \\
\hline \multicolumn{4}{|c|}{ PRAIRIE } \\
\hline National forest & -- & -- & -- \\
\hline Other federal & 4.4 & 3.3 & 1.1 \\
\hline \multicolumn{4}{|l|}{ State, county } \\
\hline and municipal & 13.1 & 5.4 & 7.7 \\
\hline Forest industry & -- & -- & -- \\
\hline Farmer & 23.2 & -- & 23.2 \\
\hline Miscellaneous & & & \\
\hline private & 6.6 & -- & 6.6 \\
\hline All owners & 47.3 & 8.7 & 38.6 \\
\hline
\end{tabular}


Table 25.--Area of noncommercial forest land by forest type and Forest Survey Unit, Minnesota, 1977

(In thousand acres)

\begin{tabular}{|c|c|c|c|}
\hline \multicolumn{4}{|c|}{ ALL UNITS } \\
\hline Forest type & $\begin{array}{c}\text { A11 } \\
\text { areas }\end{array}$ & $\begin{array}{l}\text { Productive- } \\
\text { reserved } \\
\text { areas }\end{array}$ & $\begin{array}{l}\text { Unproductive } \\
\text { areas }\end{array}$ \\
\hline Jack pine & 211.0 & 208.2 & 2.8 \\
\hline Red-white pine & 79.4 & 71.9 & 7.5 \\
\hline Spruce-fir & 171.9 & 104.7 & 67.2 \\
\hline Black spruce & $1,101.1$ & 68.7 & $1,032.4$ \\
\hline Northern white-cedar & 148.6 & 12.6 & 136.0 \\
\hline Tamarack & 177.0 & 3.2 & 173.8 \\
\hline Oak-hickory & 111.6 & 11.4 & 100.2 \\
\hline Elin-ash-cottonwood & 225.9 & 38.3 & 187.6 \\
\hline Mapl e-basswood & 30.7 & 23.1 & 7.6 \\
\hline Aspen-birch & 743.0 & 633.9 & 109.1 \\
\hline Nonstocked & 13.9 & 2.6 & 11.3 \\
\hline All types & $3,014.1$ & $1,178.6$ & $1,835.5$ \\
\hline \multicolumn{4}{|c|}{ ASPEN-BIRCH } \\
\hline Jack pine & 203.2 & 202.0 & 1.2 \\
\hline Red-white pine & 65.0 & 59.2 & 5.8 \\
\hline Spruce-fir & 149.6 & 100.2 & 49.4 \\
\hline Black spruce & 709.2 & 62.9 & 646.3 \\
\hline Northern white-cedar & 104.8 & 12.4 & 92.4 \\
\hline Tamarack & 104.2 & 3.0 & 101.2 \\
\hline 0ak-hickory & 2.7 & 0.2 & 2.5 \\
\hline Elm-ash-cottonwood & 44.9 & 8.9 & 36.0 \\
\hline Maple-basswood & 13.8 & 9.5 & 4.3 \\
\hline Aspen-birch & 609.1 & 589.7 & 19.4 \\
\hline Nonstocked & 13.9 & 2.6 & 11.3 \\
\hline All types & $2,020.4$ & $1,050.6$ & 969.8 \\
\hline \multicolumn{4}{|c|}{ NORTHERN PINE } \\
\hline Jack pine & 4.3 & 2.7 & 1.6 \\
\hline Red-white pine & 6.7 & 6.7 & -- \\
\hline Spruce-fir & 15.5 & 1.4 & 14.1 \\
\hline Biack spruce & 382.6 & 5.8 & 376.8 \\
\hline Northern white-cedar & 43.8 & 0.2 & 43.6 \\
\hline Tamarack & 69.8 & 0.2 & 69.6 \\
\hline 0ak-hickory & 10.7 & -- & 10.7 \\
\hline Elm-ash-cottonwood & 132.9 & 4.2 & 128.7 \\
\hline Maple-basswood & 7.5 & 5.5 & 2.0 \\
\hline Aspen-birch & 80.0 & 20.2 & 59.8 \\
\hline Nonstocked & -- & -- & -- \\
\hline All types & 753.8 & 46.9 & 706.9 \\
\hline
\end{tabular}

(Table 25 continued)

\begin{tabular}{lrrr}
\multicolumn{4}{c}{ CENTRAL HARDWOODS } \\
\hline Forest type & $\begin{array}{c}\text { A1 } 1 \\
\text { Productive- } \\
\text { reserved } \\
\text { areas }\end{array}$ & $\begin{array}{c}\text { Unproductive } \\
\text { areas }\end{array}$ \\
\hline Jack pine & 3.5 & 3.5 & -- \\
Red-white pine & 7.7 & 6.0 & 1.7 \\
Spruce-fir & 4.2 & 0.5 & 3.7 \\
Black spruce & 6.6 & -- & 6.6 \\
Northern white-cedar & -- & -- & -- \\
Tamarack & 3.0 & -- & 3.0 \\
Oak-hickory & 81.6 & 8.6 & 73.0 \\
Elm-ash-cottonwood & 41.9 & 22.1 & 19.8 \\
Maple-basswood & 8.0 & 8.0 & -- \\
Aspen-birch & 36.1 & 23.7 & 12.4 \\
Nonstocked & -- & -- & -- \\
All types & 192.6 & 72.4 & 120.2 \\
\hline & PRAIRIE & & \\
\hline Jack pine & -- & -- & -- \\
Red-white pine & -- & -- & -- \\
Spruce-fir & 2.6 & 2.6 & -- \\
Black spruce & 2.7 & -- & 2.7 \\
Northern white-cedar & -- & -- & -- \\
Tamarack & -- & -- & -- \\
Oak-hickory & 16.6 & 2.6 & 14.0 \\
Elm-ash-cottonwood & 6.2 & 3.1 & 3.1 \\
Maple-basswood & 1.4 & 0.1 & 1.3 \\
Aspen-birch & 17.8 & 0.3 & 17.5 \\
Nonstocked & -- & -- & -- \\
All types & 47.3 & 8.7 & 38.6 \\
\hline & & & \\
\hline & & &
\end{tabular}





$$
\begin{aligned}
& \text { asDII } \\
& \text { A35 } \\
& \text { Cyy2 }
\end{aligned}
$$$$
88
$$

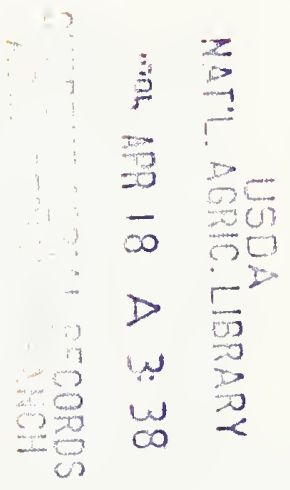


. 
MAJOR FOREST TYPES - MINNESOTA

1977 INVENTORY

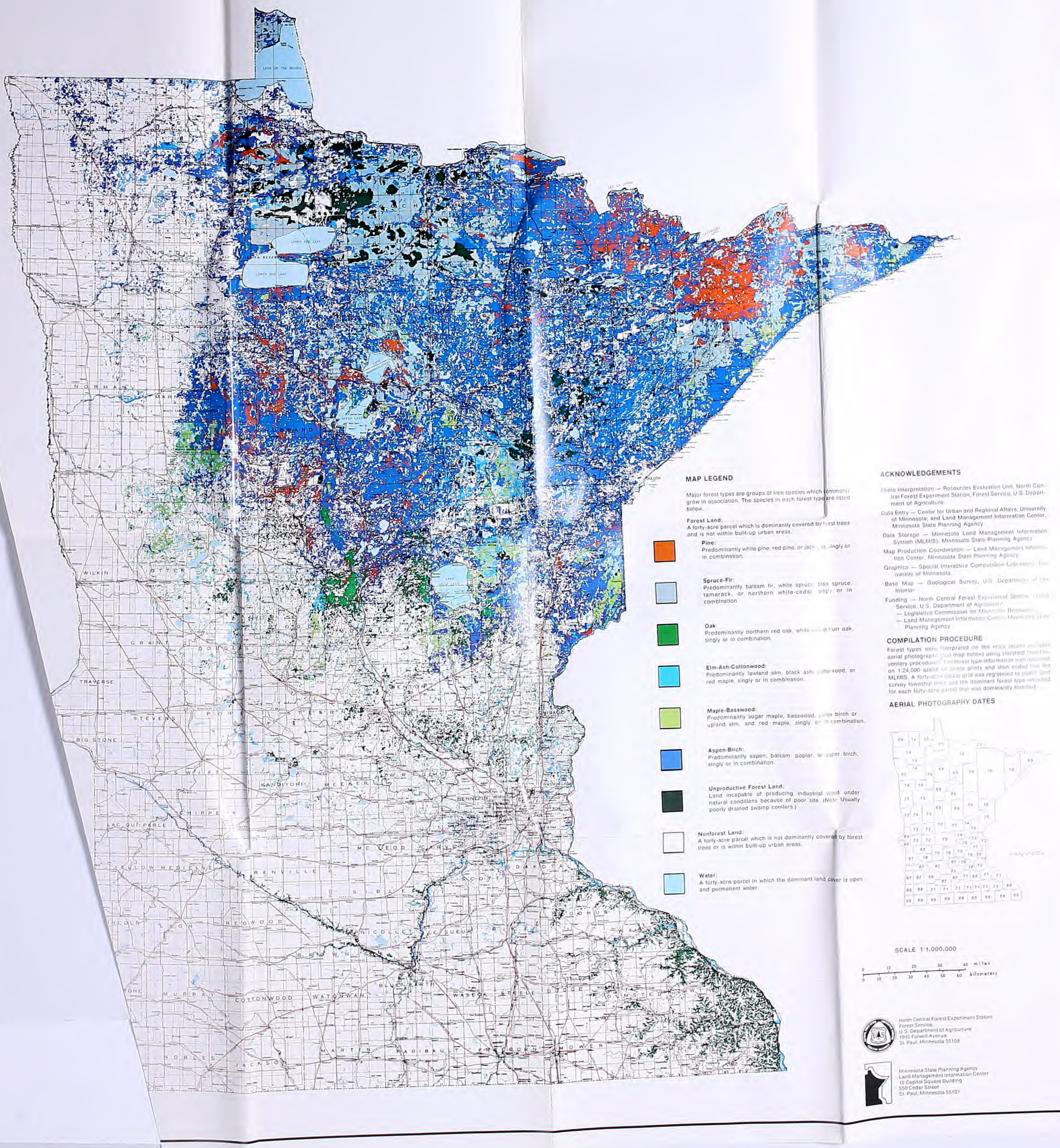


